\title{
Huey P. Long and the Guarantee Clause
}

\author{
Gerard N. Magliocca*
}

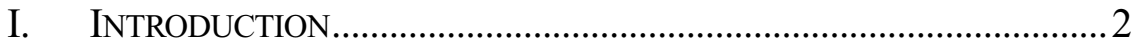

II. THE REALM OF THE KINGFISH ....................................................... 7

A. Building a Machine: Governor Long ................................. 7

B. Shutting Off Dissent: Senator Long .................................... 12

1. Ending Lawmaking Inertia and Accountability ......... 12

a. Greasing the Legislative Skids ......................13

b. Eviscerating the Courts..................................14

c. Controlling the Election Machinery ...............17

2. Quashing Resistance by Force ................................... 18

a. Free Press Under Attack................................18

b. Local Government and Political

Vengeance ....................................................20

c. The Beginning of a Police State ....................21

III. THE SLEEPING GIANT AWAKENS ..............................................22

A. The Patrician versus the Populist.......................................23

B. Popular Constitutionalism in Action..................................25

C. Weighing the Merits of Federal Action ................................2 29

1. Contents of the DOJ Memo ........................................29

2. Historical and Institutional Shadows .............................32

D. Constitutional Mobilization and a Hail of Bullets................33

IV. A ConstitUTIONAL BLACK SWAN..................................................35

A. The Guarantee Clause and Judicial Supremacy.................. 37

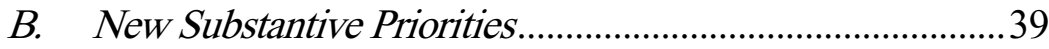

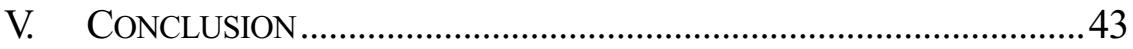

C 2008 Gerard N. Magliocca. Fulbright-Dow Distinguished Research Chair, Roosevelt Study Center; Professor of Law, Indiana University-Indianapolis. Many thanks to Dan Cole, William Leuchtenberg, Michael Pitts, Amanda Tyler, and the attendees at the presentation of this Article before the American Society of Legal History for their comments on earlier drafts. Additional thanks are owed to the FDR Presidential Library, the Hill Memorial Library at Louisiana State University, and the Roosevelt Study Center in Middleburg, the Netherlands, for their assistance with my research. 
The Constitution says that "The United States shall guarantee to every State in this Union a Republican Form of government" and it is open to question whether Louisiana now has a republican form of government.... It is difficult to say ... whether affairs in Louisiana have actually reached a point where Federal intervention under Article IV, Section 4 of the Constitution is required.... But things have gone quite far enough in Louisiana to warrant very serious consideration of the question....

-Walter Lippmann (February 5, 1935)

The enclosed memorandum from the Attorney General in regard to "What is a Republican Form of Government" is interesting. Will you let me have it back when you have read it?

-Franklin D. Roosevelt (April 20, 1935)

A House committee, with Representative Granfield, Democrat, at its head, will investigate Mr. Long's "dictatorship" in Louisiana. It is expected to inquire whether that State, under Mr. Long's leadership, enjoys "a republican form of government" as guaranteed by the Constitution.

—New York Times (one week before Long's assassination)

\section{INTRODUCTION}

Even among the outsized intellects and egos of the New Deal, nobody stood out like "The Kingfish"-Huey P. Long. ${ }^{4}$ Justice Hugo Black said that Long had "one of the very best minds I've ever met." Lyndon B. Johnson, who was a young congressional aide at the time, recalled that he "was simply entranced by Huey Long" because "[f]or

1. Walter Lippman, Today and Tomorrow, N.Y. Herald TRIB., Feb. 5, 1935, at 19.

2. Memorandum from President Franklin D. Roosevelt to the Vice President and Senator Robinson (Apr. 20, 1935) (on file with the FDR Library).

3. The Nation, N.Y. TIMES, Sept. 1, 1935, at E1. Senator Long was shot on September 8, 1935, and died shortly thereafter. See Allan P. SindLER, HuEY Long's LOUISIANA: STATE POLITICS, 1920-1952, at 96 (1956).

4. See David M. Kennedy, Freedom from Fear: The American People in DEPRESSION AND WAR, 1929-1945, at 235 (1999) ("Other than Franklin Roosevelt himself, no figure flashed more incandescently across the Depression-darkened American political landscape."); see also HARNETT T. KANE, LOUISIANA HAYRIDE: THE AMERICAN REHEARSAL FOR DICTATORSHIP 1928-1940, at 79 (1941) (explaining how Long acquired his nickname).

5. Roger K. Newman, Hugo Black: A Biography 196 (1994); see also Tom Wicker, Huey Long, N.Y. TIMES, Nov. 2, 1969, at BR1 ("Huey Long was about the smartest man I ever knew." (quoting Senator Richard B. Russell)). Long won a case before the United States Supreme Court when he was just twenty-nine. See Cumberland Tel. \& Tel. Co. v. La. Pub. Serv. Comm'n, 260 U.S. 212, 220 (1922); see also AlAn BRINKLEY, VoICES OF PROTEST: Huey Long, Father Coughlin, And the Great Depression 10 (Vintage Books 1983) (1982) (stating that Long was born in 1893); T. HARRY WILliAMS, HuEY LONG 162-73 (1969) (chronicling the litigation). 
leading the masses and illustrating your point humanly, Huey Long couldn't be beat." Franklin D. Roosevelt was not such a fan, telling his inner circle that the Louisiana Senator was "one of the two most dangerous men in America." And Harry Truman, with his flair for understatement, called the Kingfish as "crooked as a ram's horn" and "nothing but a damned demagogue.",

Novelists and historians are drawn to these dueling depictions of Huey Long because they represent a deeper ambivalence about the populist movement that he led.' In Louisiana, he forged the most liberal record of any Southern politician during Jim Crow. ${ }^{10}$ Long abolished the poll tax, provided free textbooks to children, poured money into public infrastructure, and made the tax burden more progressive." In Washington, the Senator founded the "Share Our Wealth" society, which attracted a national following with its pledge to redistribute wealth and end poverty under the banner of "Every Man a

6. Richard D. White, JR., Kingfish: The Reign of Huey P. Long 146 (2006).

7. ARThur M. SChlesinger, JR., The POlitics of UPHEAVAl 55 (1960); see WILLIAMS, supra note 5, at 640 (stating that FDR's other nominee for "most dangerous" was Douglas MacArthur); $c f$. WiLliam Ivy HAIR, THE KINGFish AND His REALM: THE LiFE AND TIMES OF HuEY P. LONG 309 (1991) (quoting H.G. Wells' comment that Long was "a Winston Churchill who has never been to Harrow").

8. WHITE, supra note 6, at 259.

9. See Raymond Gram Swing, Forerunners of AmErican FASCiSm 75 (1935) ("Taken all in all, I do not know any man who has accomplished so much that I approve of in one state in four years, at the same time that he has done so much that I dislike."). Long was the inspiration for Willie Stark, the idealistic lawyer turned ruthless boss in what may be the greatest American political novel. See Robert Penn Warren, All The King's Men (1946); see also SCHLESINGER, supra note 7, at 60 ("A young man in the English Department at [LSU] named Robert Penn Warren was fascinated by the phenomenon of Long; the result was the astute and compassionate novel, All the King's Men.").

10. Though Long did not challenge segregation, he was viewed as one of the strongest white supporters of African-American rights in the South. See Wicker, supra note 5 (relating Long's view that "[y]ou can't help poor white people without helping Negroes"). Following his death, the New York Herald Tribune commented that "Southern Democratic leaders, while shocked by the tragic manner of Senator Long's going, were profoundly relieved at the thought that the tendency toward increased Negro voting had lost its chief champion." Theodore C. Wallen, Long To Be Buried in His Capitol's Lawn, N.Y. HeRALD TRIB., Sept. 11, 1935, at 1.

11. See, e.g., HAIR, supra note 7, at 278 (stating that Long pushed through a constitutional amendment to abolish the poll tax); Hodding Carter \& Gerald L.K. Smith, How Come Huey Long?, New Republic, Feb. 13, 1935, at 11, 12 ("He has ordained a twothousand-dollar homestead exemption .... He has granted a two-year debt moratorium .... Add all that to paved roads, free schoolbooks and a continual taxation harrying of the Standard Oil and the public utilities, ... and you get a pretty good idea of why the doctrine of wealth sharing has taken hold among the poor whites, who constitute the majority of Louisiana's electorate."). 
King, but No Man Wears a Crown." ${ }^{\text {,2 }}$ At the same time, Long's assault on civil liberties and democracy was so great that he was regularly compared to Hitler. ${ }^{13}$ For instance, the Kingfish set up a secret police force that could act without warrants, established a censor board to prevent criticism of his rule, required lawyers to obtain a license from his machine's bar association, and imposed martial law without any opportunity for judicial review. ${ }^{14}$ The mystery of what Long represented was never resolved because the Kingfish was gunned down just as he was about to launch a presidential bid against FDR. ${ }^{15}$

This Article contends that Long's assassination was a crucial turning point in the evolution of New Deal constitutionalism. ${ }^{16}$ In

12. See SCHLESINGER, supra note 7, at 45-46 (stating that the motto came from William Jennings Bryan). The essence of the Share Our Wealth proposal was a minimum income guarantee combined with a cap on what any household could own. See Huey P. Long, Radio Address, in Lend Me Your EARS: GREAT SpeECHES IN History 580, 582 (William Safire ed., 1992) ("We propose to limit the wealth of big men in the country.... We will not say we are going to try to guarantee any equality .... [B]ut we do say that onethird of the average is low enough for any one family to hold ....").

13. See, e.g., Editorial, The Kingfish's Putsch, Detroit Free Press, Aug. 18, 1934, at 6 ("While Adolf Hitler was setting the stage in Germany for an 'election' to confirm his dictatorship, Senator Huey P. Long stood on the floor of the Louisiana Legislature and shouted his orders to a subservient House ...."); Text of General Johnson's Denouncement of Father Coughlin and Huey Long, N.Y TIMES, Mar. 5, 1935, at 10 ("Huey is a dictator by force of arms and Adolf Hitler has nothing on him any way you care to look at them both. In fact Huey is the Hitler of one of our sovereign States. ..."). Of course, comparisons with Hitler during the mid-1930s were not the same as comparisons to the genocidal Hitler of World War II.

14. See, e.g., HAIR, supra note 7, at 165 (stating that the Bureau of Criminal Identification could "make arrests anywhere in the State of Louisiana, without warrants"); Carter \& Smith, supra note 11, at 12 (" $[\mathrm{H}]$ is secret state police force, its identity and numbers known only to the administration, can take you out of your home whenever it likes and hold you incommunicado on whatever charge may be necessary."); see also WHITE, supra note 6, at 237 (stating that Long created a censor board to review newsreels); Huey Long Troops Force His Foes To Surrender; Martial Law Declared, N.Y. TIMES, Jan. 27, 1935, at 1 [hereinafter Martial Law] (describing one example of Long's use of force); Letter from J. Edgar Hoover, Dir., Div. of Investigation, Dep’t of Justice, to Marvin H. McIntyre, Assistant Sec'y to the President (Aug. 18, 1934) (on file with the FDR Library) (describing a state law barring "court interference by injunction or otherwise with national guards").

15. See KENNEDY, supra note 4, at 241 (quoting FDR's view that "Long plan[ned] to be a candidate of the Hitler type for the presidency in 1936"); Editorial, Florida Jittery on Long Campaign, N.Y. TIMES, Aug. 11, 1935, at E6 ("[T] he Louisiana dictator is getting down to business in his campaign for delegates to 'stop Roosevelt' in the Democratic convention."); see also Felix Belair Jr., Radical Party Wedge Goes with Huey Long, N.Y. TIMES, Sept. 15, 1935, at E3 ("[W]ith the Dictator of Louisiana passed the threat of an effective ultra-radical independent movement to prevent the reelection of President Roosevelt.").

16. The significance of Long's movement and his assassination are totally ignored by lawyers. For example, the leading treatment on the constitutional politics of the New Deal says nothing about him or how the Share Our Wealth platform pushed FDR into supporting the reforms of the "Second New Deal" in 1935. See 2 Bruce Ackerman, We the People: TRANSFORMATIONS 296-302 (1998) (arguing that these developments, most notably the Social 
response to his unprecedented concentration of power, citizens and journalists across the country started asking if Louisiana still had a republican form of government. ${ }^{17}$ Officials in Washington, who were desperate to derail the Kingfish's growing ambition, seized on this outbreak of popular constitutionalism and started discussing the possibility of invoking the Guarantee Clause and disbanding Long's regime. $^{18}$ In August 1935, the House of Representatives began that process by forming a special committee to investigate conditions in Louisiana and issue a report. ${ }^{19}$ Within a few weeks, however, Long was killed, and this last serious effort to use the Guarantee Clause was rendered moot.

By cutting this constitutional confrontation short, Long's assassin unintentionally altered the institutional and substantive outcomes that emerged from the New Deal. But for this shocking event, the special committee would have probably issued a report defining (1) which rights being infringed in Louisiana were fundamental and (2) which institutional practices in the state were so abusive that they struck at

Security Act, were a response to Schechter Poultry Corp. v. United States). More important, I cannot find any law review articles that examine the authoritarian regime established by Long. The closest example is a fine book by Richard C. Cortner on the fight over freedom of the press in Louisiana. See Richard C. Cortner, The Kingfish And the Constitution: Huey Long, the First Amendment, AND the EMERGENCE of Modern Press FreEdom IN AMERICA (1996); see also Grosjean v. Am. Press Co., 297 U.S. 233, 250-51 (1936) (voiding Long's advertising tax on newspapers).

17. See, e.g., Letter from Mrs. Bessie Zelnik to Franklin D. Roosevelt (Jan. 27, 1935) (on file with the FDR Library) ("[S]ince the Constitution guarantees to the States a Republican form of government, I do not understand how Huey Long ... is allowed to assume such dictatorial powers in his State particularly since he is not even a member of the Louisiana State Legislature."); see also U.S. CONST. art. IV, § 4 ("The United States shall guarantee to every State in this Union a Republican Form of Government ....").

18. See Memorandum from Alexander Holtzoff to the Att'y Gen. 1 (Apr. 12, 1935) (on file with the FDR Library) [hereinafter Holtzoff Memo] ("I submit herewith a memorandum, which I have prepared, on the constitutional guaranty to the states of a republican form of government, especially in relation to the present situation existing in Louisiana."); $c f$. Adam H. Kurland, The Guarantee Clause as a Basis for Federal Prosecutions of State and Local Officials, 62 S. CAL. L. REV. 367, 447 (1989) (stating that "Long turned Louisiana into a twentieth century laboratory to test the application of the guarantee clause").

19. See Louisianans Push an Inquiry of Long, N.Y. TIMES, Aug. 29, 1935, at 10 (explaining that this resolution "empowered the committee to investigate Long's political organization, including his five-day State legislative sessions and their effect upon the republican form of government guaranteed by the Constitution"). One reason the Guarantee Clause issue does not receive more attention is that many scholars rely on an erroneous statement in Arthur M. Schlesinger's series on the New Deal, in which he says that the President rejected the idea of challenging Long in this way. See SCHLESINGER, supra note 7, at 250-51; infra text accompanying notes 148-160. 
the heart of self-government. ${ }^{20}$ Such a report, coming in the midst of a collapse of long-standing assumptions about the role of the federal government, would have been an authoritative act of constitutional interpretation on major issues such as incorporation, voting rights, and the status of political minorities that would have exerted a powerful influence on subsequent judicial decisions. ${ }^{21}$ From a structural standpoint, this heightened congressional involvement at a critical stage of the New Deal could have set a precedent in support of a more cooperative system of constitutional development and weakened the claims of judicial exclusivity in interpretation. ${ }^{22}$ On the substantive side, congressional action or litigation challenging Long's dictatorship may well have accelerated federal protection of voting rights and the incorporation of the Bill of Rights by nearly three decades. ${ }^{23}$

Part II explores the petty tyranny that arose in Louisiana during the 1930s. Part III reviews the calls for action against this dictatorship, which focused on invoking the Guarantee Clause and placing the state into federal receivership. Finally, Part IV considers how the New Deal might have unfolded differently in a counterfactual world where Huey Long was not murdered.

20. Richard Primus makes a strong argument that constitutional law after the New Deal was influenced by a reaction against the abuses of foreign tyrants. See RicHARD A. Primus, The American Language OF Rights 197-213 (1999) (looking at Supreme Court cases on incorporation, racial discrimination, and other issues that expressly referred to Nazi and Soviet counterexamples). This Article builds on that insight and shows that the theme of "anti-totalitarianism" began earlier in response to the Kingfish and would have drawn more on domestic examples had he lived longer. See infra text accompanying notes 181-190.

21. This action, especially if taken by Congress as a whole, would have been authoritative because the Guarantee Clause is not justiciable. See Pac. States Tel. \& Tel. Co. v. Oregon, 223 U.S. 118, 143-50 (1912) (holding that the Guarantee Clause raises a political question). Nevertheless, there is a relationship between the definition of republican government and the justiciable textual clauses that makes any declaration by Congress on the former powerful guidance for courts. See infra text accompanying notes 176-179.

22. By judicial exclusivity, I mean the robust view that the federal courts are "supreme in the exposition of the law of the Constitution." Cooper v. Aaron, 358 U.S. 1, 18 (1958) (per curiam). Even under the cooperative system outlined in the text, the Supreme Court's judgments would be final. The point is that Congress would have a much greater ability to assert its own constitutional views under a system where the Guarantee Clause was not dormant. For a fascinating analysis of a similar dynamic that developed during the $1960 \mathrm{~s}$, see Bruce Ackerman \& Jennifer Nou, Canonizing the Civil Rights Revolution: The People and the Poll Tax, 103 Nw. U. L. REV. (forthcoming 2009) (manuscript on file with author) (discussing Section 10 of the Voting Rights Act and its relationship to Harper $v$. Virginia Board of Elections).

23. In other words, the substantive impact of Long's assassination does not require an assumption of congressional action pursuant to the Guarantee Clause. Litigation, some of which was in the pipeline when Long was killed, could have accomplished the same end by focusing attention on his constitutional abuses. 


\section{THE REALM OF THE KINGFISH}

Freedom cannot be fully understood without studying its failures. In 1934, Senator Tom Connally told his colleagues, "I advise anyone who thinks he knows something about politics to go down to Louisiana and take a postgraduate course. ${ }^{, 24}$ This Part follows his advice and takes a hard look at the construction of the first and only dictatorship in American history. ${ }^{25}$ As Long tightened his hold over the state, even while serving as a U.S. senator with no legal authority in Louisiana, the national press began to wonder whether this was a laboratory for the future. ${ }^{26}$

\section{A. Building a Machine: Governor Long}

Huey Long began his career as a populist whose tactics were indistinguishable from a local ward boss like Richard J. Daley or the leaders of Tammany Hall. After a meteoric rise, the Kingfish was elected governor in 1928 on a pledge to break the power of wealthy

24. HAIR, supra note 7, at 257. Connally made this comment after chairing a set of hearings into the election of John Overton, who was backed by the Long machine in a Senate campaign littered with fraud and dirty tricks. See WiLliams, supra note 5, at 683-86 (describing the Overton investigation).

25. It is my hope that this Article will create more interest in the Long regime among legal scholars. There is a great deal to learn from how lawyers deal with injustice embedded in positive law. See generally RoBERT M. COVER, Justice ACCUSED: ANTISLAVERY AND THE JUDICIAL PROCESS (1975) (exploring how antislavery judges decided slavery cases). Since the Hart-Fuller debate, however, this discussion has focused largely on Nazi Germany. Compare Lon L. Fuller, Positivism and Fidelity to Law-A Reply to Professor Hart, 71 HARV. L. REV. 630, 633 (1958) ("Without any inquiry into the ... legal system under the Nazis, Professor Hart assumes that something must have persisted that still deserved the name of law in a sense that would make meaningful the ideal of fidelity to law."), with H.L.A. Hart, Positivism and the Separation of Law and Morals, 71 HARV. L. REV. 593, 617 (1958) (addressing the "failure of the German legal profession to protest against the enormities which they were required to perpetrate in the name of law").

In my view, Long's Louisiana is a better natural experiment for thinking about profound issues such as the connection between positive law and morality or the responsibilities of the legal profession in a time of crisis. It is increasingly difficult to use the Third Reich as anything other than an epithet because the crimes of the Nazis approach a platonic ideal of evil. By contrast, the events that unfolded in Louisiana present a slide into authoritarianism without any killings and in a domestic political culture that is easier to understand. Thus, there are a host of untapped teaching and research resources from this time that I will try to highlight in subsequent footnotes.

26. See HAIR, supra note 7, at 294 ("[N] ewspapers and magazines descended on Baton Rouge to gape at the 'Longislature.'... O On one point of speculation virtually all agreed: if the Kingfish ever did occupy the White House, he would try to run America as he was running Louisiana."); Westbrook Pegler, "Should U.S. Fear Dictator Huey?" Writer Urges Peek at His Record, PITTSBURGH PRESS, Apr. 17, 1935, at 5 ("[E]very good reporter who has gone into Louisiana has come away confirming the existence of a dictatorship ...."). 
interests and deliver badly needed services to the poor. ${ }^{27}$ In his best campaign speech, Long stood beneath the oak tree where Evangeline waited in vain for her lover in the Longfellow poem and asked:

Where are the schools that you have waited for your children to have, that have never come? Where are the roads and the highways that you send your money to build, that are no nearer now than ever before? Where are the institutions to care for the sick and the disabled? Evangeline wept bitter tears in her disappointment, but it lasted through only one lifetime. Your tears in this country, around this oak, have lasted for generations. Give me the chance to dry the eyes of those who still weep here. ${ }^{28}$

By all accounts, the Governor made a good start on fulfilling this promise in his first legislative session, pushing through measures that revised the tax code, lowered the price of natural gas for New Orleans, and boosted funding for public education and roads. ${ }^{29}$

Like any canny leader, the Governor used the patronage at his disposal to build support for his agenda, though he was particularly aggressive in wielding this power. For example, Long required all of his appointees to sign undated letters of resignation so that he could remove them at any time. ${ }^{30}$ He also persuaded the legislature to take many agencies and boards from the civil service so that he could fill those positions with political appointees. ${ }^{31}$ Helpful legislators were given some of these jobs, while opponents with relatives on the state payroll were told that if they voted the wrong way, their family members would be fired. ${ }^{32}$ As the Great Depression deepened over the next several years, this economic leverage allowed the Kingfish to

27. See KANE, supra note 4, at 47-58 (chronicling Long's election to the state railroad commission at the age of twenty-five and his narrow defeat in the 1924 gubernatorial election).

28. White, supra note 6, at 33; see HENRY WADSWORTH LONGFELlOW, EvangELINE, A TALE OF ACADIE (6th ed. 1848).

29. See, e.g., BRINKLEY, supra note 5, at 24; SINDLER, supra note 3, at 58-59; WiLliams, supra note 5, at 299-310. When Long's plan to give free textbooks to public and Catholic schools was resisted on the ground that the state's "Blaine Amendment" barred public funding of religious activity, he argued that the program would be constitutional if the books were given to the children. See WHITE, supra note 6, at 55; see also Borden v. La. State Bd. of Educ., 123 So. 655, 660-61 (La. 1929) (opinion of Overton, J.) (upholding the free textbook program). Thus, Long pioneered the theory that was used much later to defend parochial school vouchers against an Establishment Clause attack. See Zelman v. SimmonsHarris, 536 U.S. 639, 649 (2002) (drawing a distinction between money given directly to religious schools and money given to private parties that would indirectly aid religious organizations).

30. See White, supra note 6, at 44; WILliAMS, supra note 5, at 293-94.

31. WHITE, supra note 6, at 44.

32. WILLIAMS, supra note 5, at 296. 
stifle dissent among critics who literally could not have survived without a state job. ${ }^{33}$

While Long's use of patronage was within the bounds of accepted practice, some of his other methods were more disturbing. First, there was his creation of the Bureau of Criminal Identification (BCI), a state police force that was controlled by the Governor and authorized to make arrests without warrants. ${ }^{34}$ Second, Long sent the National Guard into New Orleans to smash gambling establishments, even though state law prohibited the use of troops as a police force. ${ }^{35}$ Third, there was his infuriating habit of appearing personally on the floor of the legislature to bark orders at his supporters and browbeat his foes. ${ }^{36}$ Such flagrant disregard for separation of powers drew the ire of one legislator who threw a copy of the state constitution at the Kingfish and said, "Maybe you've heard of this book," to which Long replied, "I'm the constitution just now."

Frustration with these bare-knuckle tactics and opposition by Standard Oil to the Governor's proposed tax on refined petroleum led to Long's impeachment in $1929 .^{38}$ Although charged with eight counts, including bribery, the Kingfish convinced fifteen senators - one more than needed - to sign a letter saying that they would not vote for a

33. WHITE, supra note 6, at 91. Patronage also served as a source of campaign funds, as state employees "volunteered" to give five to ten percent of their salary to a slush fund controlled by Long. See BRINKLEY, supra note 5, at 27 (describing the "deduct box"); WhITE, supra note 6, at 91 ("When the squeeze was put on them for more contributions, they ... shelled out for tickets to the machine-controlled baseball park or took out another subscription to the machine-owned newspaper.").

34. See WHITE, supra note 6, at 46 ("Secretive and powerful, the BCI provided Huey with a hefty political weapon and signaled an ominous first step toward creation of a police state.'); J.E. Crown, Louisiana Mobilizes Opposition to Long, N.Y. TIMES, Jan. 27, 1935, at E7 (calling the BCI "Long's secret police").

35. See WHITE, supra note 6, at 54 (explaining that the state attorney general said these raids proceeded into "the teeth of the law"); WILLIAMS, supra note 5, at 343 (quoting Long's answer that he had "paid no attention to, and [would] pay no attention to any opinion of the Attorney General protecting the gambling interests").

36. See KANE, supra note 4, at 64 ("Once or twice he walked into legislative committee meetings, took over, and told his men how to vote."); WILLIAMS, supra note 5, at 298 ("[O]n crucial bills, he insisted on acting as his own floor leader. . . . On a voice vote, he would sometimes himself answer for one of his adherents, bellowing the vote he wanted the man to cast.").

37. WhITE, supra note 6, at 45 .

38. See Williams, supra note 5, at 356-62 (describing the events of "Bloody Monday"); see also BRINKLEY, supra note 5, at 25 (stating that the Standard Oil band provided free music at a pro-impeachment rally); SCHLESINGER, supra note 7, at 47 ("Standard Oil and other corporations feared the tax as a fatal precedent. Constitutionalists thought that Huey Long's technique of personal government was threatening democracy."). 
conviction under any circumstances. ${ }^{39}$ While these senators were rewarded with various sugarplums, Long vowed to crush his enemies once and for all. ${ }^{40}$ Indeed, many historians argue that this traumatic event changed him from just another ambitious politician into a ruthless dictator. ${ }^{41}$ Reflecting on the impeachment trial, Long said, "I used to try to get things done by saying 'please.' That didn't work and now I'm a dynamiter. I dynamite 'em out of my path., ${ }^{, 2}$

To break the deadlock in the legislature and obtain a renewed mandate, the Kingfish announced that he would run for the Senate in 1930 and make the election a referendum on his agenda. ${ }^{43}$ Long then added that if he won, he would stay on as Governor until his term ended and leave his Senate seat vacant. ${ }^{44}$ While election as a senator and a governor simultaneously was not unprecedented, this maneuver did not bode well for republican government in the state. ${ }^{45}$

39. See CORTNER, supra note 16, at 28 (listing the charges in the articles of impeachment); WHITE, supra note 6, at 86-87 (describing the declaration of the "Round Robin" group). When the Chief Justice was asked to recuse himself from presiding over the trial, he allegedly said, "Don't they think that I'll give the thieving sonofabitch a fair trial?" WILLIAMS, supra note 5, at 383.

40. See KANE, supra note 4, at 77 ("The Famous Fifteen, who had signed the Round Robin document at the impeachment, cashed in."); see also BRINKLEY, supra note 5, at 26 ("Long moved in the months and years after the 1929 special session to erect a structure of personal power in Louisiana unprecedented in its extent and often frightening in its implications.").

41. See SinDLER, supra note 3, at 67 ("The abortive impeachment of Long thus served to intensify his class program and his lust for personal power."); WHITE, supra note 6, at 90 ("After he barely survived impeachment, he no longer seemed the same ....").

42. BRINKLEY, supra note 5, at 25; SCHLESINGER, supra note 7, at 47. The notion that the impeachment served as an epiphany for Long is dubious and recalls one author's description of the futile search for the "No More Mr. Nice Guy" moment that turned Hitler into a maniac. See Ron Rosenbaum, Explaining Hitler: The SEARCh For the Origins of His EvIL, at xxxv (1998) (explaining that many historians are still seeking to explain Hitler's evil by searching for a specific psychological turning point).

43. See KANE, supra note 4, at 82; SCHLESINGER, supra note 7, at 48.

44. See WiLliamS, supra note 5, at 460-61; see also SinDLER, supra note 3 , at 70 ("Thus ensued the curious spectacle of a governor running for the United States Senate on the public understanding that he would not leave the governorship for two more years and on a platform pledging a state good-roads program.”).

45. See WHITE, supra note 6, at 106 (noting that Hiram Johnson and Robert LaFollette also had overlapping Senate and gubernatorial terms). The growing threat to democracy was highlighted by one notorious incident in which Long ordered the state police to arrest two men who were planning to expose graft in his administration a week before the primary. See CORTNER, supra note 16, at 53 (describing the arrest of Sam Irby and James Terrell); WILLIAMS, supra note 5, at 473 (arguing that the concern was about the exposure of Long's mistress). When a writ of habeas corpus was issued against Long, he denied knowing where the men were. See WhITE, supra note 6, at 111. On the eve of the election, though, he produced one of them who said that he had not been kidnapped. See KanE, supra note 4, at 84 ("Huey permitted reporters a glimpse at a frightened-looking individual, who was then whisked away by bodyguards ...."); WILLIAMS, supra note 5, at 475 ("Irby obviously had 
Nevertheless, the Kingfish won a smashing victory in the Democratic primary - the only election that mattered - with fifty-seven percent of the vote. ${ }^{46}$ He then declared himself "Governor and Senator-Elect" in spite of the legal objections (and an attempted coup) by the Lieutenant Governor. $^{47}$

In 1932, Long consolidated his hold on the state by arranging the election of his friend, Oscar "O.K." Allen, as the next governor at the head of a pro-machine slate. ${ }^{48}$ Allen earned the nickname "O.K." because he was nothing more than a puppet that followed Long's orders. ${ }^{49}$ Earl Long, the Kingfish's brother, once remarked, "A leaf once blew in the window of Allen's office and fell on his desk. Allen signed it." ${ }^{90}$ With O.K. Allen in the governor's chair and an increased

been coached as to his part in the scene. As Huey held before him the statement that he had signed, Irby read it.").

46. See WiLliams, supra note 5, at 480 (stating that Long faced no challenge in the general election); see also SINDLER, supra note 3, at 73 ("Huey increased his proportion of the state vote from 43.9 per cent in 1928 to 57.3 per cent in $1930 \ldots$...").

47. See SINDLER, supra note 3, at 76 (stating that the Lieutenant Governor "never ceased to insist upon the illegality of Huey's dual position as Governor and Senator-elect"). In 1931, the Lieutenant Governor took the oath of office and sued, claiming that Long was no longer in charge. See State ex rel. Cyr v. Long, 140 So. 13, 13-15 (La. 1932) (opinion of Brunot, J.) (producing the original petition); WILliAMS, supra note 5, at 540 (noting that the Lieutenant Governor issued a proclamation declaring himself governor). In response, the Kingfish ordered troops into the streets of Baton Rouge to guard the Capitol. See WiLliams, supra note 5, at 541; see also Huey Long Defeats Coup d'Etat by Cyr, N.Y. TIMES, Oct. 14, 1931, at 1 ("Two rival Governors struggled for supremacy in Louisiana tonight to an opera bouffe accompaniment of armed troops, artillery and fiery manifestos."). The Louisiana Supreme Court dismissed the suit on the ground that the dispute was a political question. See Cyr, 140 So. at 18 (St. Paul, J., concurring) ("[N]either this court, nor any other court, has jurisdiction to determine who is the Governor of the state of Louisiana."); id. at 17 (opinion of Brunot, J.) (adding that the only means of removing Long was impeachment); see also id. at 18 (stating that three Justices were "of the opinion that the court has jurisdiction to decide this case" but declining to reach the merits).

48. See BRINKLEY, supra note 5, at 27; see also SindLER, supra note 3, at 77 ("The outcome of the 1932 primary ... was a victory for Longism by roughly the same proportion of the state vote as Huey secured in 1930. Allen's entire ticket won office with him." (citation omitted)).

49. See, e.g., BRINKLEY, supra note 5, at 27 (reporting that, on the rare occasions when Allen tried to say something, Long would tell him to shut up); WHITE, supra note 6, at 251 (stating that Long "treated his handpicked governor, O.K. Allen, as little more than his personal errand boy who carried out his orders without question, even moving out of his office while [Long] was in town"); Political Note: Share-the-Wealth Wave, TIME, Apr. 1, 1935, at 15, 15 ("The Governor is [Long's] puppet.").

50. BRINKLEY, supra note 5, at 28. These events informed the political thought of John Minor Wisdom, who became a Republican and developed a passion for the rule of law (as expressed in his desegregation opinions) largely because of his fight against Long's machine. See Joel Wm. Friedman, John Minor Wisdom's Battle Against the Political Bosses To Create a Two-Party System in Louisiana, 69 TUL. L. REv. 1439, 1443-46 (1995) (describing the hostile encounters between the Wisdom family and Huey Long). 
majority in the legislature, Long extended his liberal reforms while also showing "how it is possible to destroy self-government while maintaining its ostensible and legal form."

\section{B. Shutting Off Dissent: Senator Long}

While the Kingfish took his flamboyant style to Washington, he sought to secure his power base in Louisiana and make it a launching pad for his presidential aspirations. This effort culminated in a series of legislative special sessions summoned in 1934 and 1935 that left the state with "less freedom, as freedom is measured by the safeguards of a constitution and a government by representation, through parliamentary forms, than has existed in any other state in the history of the union. ${ }^{, 52}$ For ease of reading, the analysis of these special sessions is broken down into two Subparts, examining (1) the procedural revolution that erased almost all checks on one-party rule and (2) the substantive policies that created a climate of fear and intimidation within the state.

\section{Ending Lawmaking Inertia and Accountability}

Let us begin by looking at the institutional innovations that Long used to silence the opposition. These practices fell into three categories: (1) destroying the right of minorities to block legislation, (2) wiping out judicial review, and (3) placing the election system under partisan control. With these measures in place, the Senator

51. Some of the Morals, N.Y. TIMES, Sept. 11, 1935, at 22. During Governor Allen's term, the legislature passed a homestead exemption that gave tax relief to the poor, reduced license fees for cars, created a debt moratorium, abolished the poll tax, and established an income tax. See SindLER, supra note 3, at 88-89; Hodding Carter, Huey Long: American Dictator, in The AsPiRIN Age 1919-1941, at 339, 354 (Isabel Leighton ed., 1976). These achievements are relegated to a footnote because they were irrelevant to the ensuing public debate about the Guarantee Clause, not because they were insignificant.

52. Tom Wallace, The Secret of Huey's Power Lies in Political Mastery, Kan. CITY STAR, Feb. 17, 1935, at 10; see SindLER, supra note 3, at 91 ("From August, 1934, through September, 1935, seven special sessions of the Legislature enacted measures which ... reduced the citizenry of Louisiana to political vassalage ...."); Long Sets Session To Widen Powers, N.Y. TIMES, Dec. 16, 1934, at 37 ("Senator Huey Long today ordered more laws to buttress his dictatorship . . ..”); Letter from J. Edgar Hoover, Dir., Div. of Investigation, Dep't of Justice, to Marvin H. McIntyre, Assistant Sec'y to the President (Aug. 19, 1934) (on file with the FDR Library) ("The consensus of opinion as expressed in New Orleans newspapers is that the passage of the 27 bills by the State Legislature allegedly at the instance of Senator Huey Long has given the Senator through the State Administration dictatorial powers, including complete dominance of election machinery and officials."). 
became, in the classic definition of tyranny, "all three branches of State government . . . executive, legislative and judicial.".53

\section{a. Greasing the Legislative Skids}

Long's power rested on his faction's dominance in the state legislature, and the Kingfish maximized that power by eliminating almost all internal procedures in that body. Starting in 1934, all bills went through the same legislative committee in each house. ${ }^{54}$ At this committee's hearings, the only witness was usually Huey Long, who would summarize the legislation before calling an immediate vote. ${ }^{55}$ The bill would then race to the floor of each chamber, where a simple majority could suspend the rules, which rendered them rules in name only. ${ }^{56}$ Lastly, Long would stand near the rostrum and order the speaker to call the question on each bill in rapid succession. ${ }^{57}$ If speed is the essence of good lawmaking, then this system was a spectacular success.

53. Thomas L. Stokes, Huey Long, Kingfish and Almost a King, N.Y. WorLd Telegram, Nov. 28, 1934, at 1; see THe Federalist No. 47, at 324 (James Madison) (Jacob E. Cooke ed., 1961) (restating Montesquieu's idea that "[t]he accumulation of all powers legislative, executive and judiciary in the same hands ... may justly be pronounced the very definition of tyranny"). Although none of the reporters covering Louisiana quoted Montesquieu (or probably knew who he was), it is amazing how many of them invoked his formulation. See Legislature Ready for New Long Bills, N.Y. TIMES, July 5, 1935, at 14 ("[T] legislative branches of the government.'); William F. McDermott, 'State, It's Me,'Is Case of Huey Long, Cleveland Plain Dealer, Feb. 18, 1935, at 1 (subtitled "He Makes Laws, Controls Judiciary and His 'Storm Troops' Enforce Them”); see also F. Raymond Daniell, Louisiana Becomes an Authoritarian State, N.Y. TiMES, Feb. 10, 1935, at E3 ("One man makes its laws and interprets and enforces them.").

54. See WHITE, supra note 6, at 261 ("Huey removed legislative oversight from other House committees and ordered that all bills proceed only through Ways and Means, which he stacked with his more trustworthy followers."); WILLIAMS, supra note 5, at 727 (explaining that the same procedure was used in the Senate); see also Huey Long Files 35 'Mystery' Bills, N.Y. TIMES, Dec. 17, 1934, at 3 ("Long dumped the bills, apparently covering a raft of odds and ends of legislation, on the House desk and then had them speeded to the Ways and Means Committee under rule suspension ....”).

55. See Williams, supra note 5, at 727 ("The committee met on the following morning to hear witnesses on the bills, but only one person testified, Senator Long, who appeared as an interested citizen."); see also BRINKLEY, supra note 5, at 28 ("Long explained in a few vague words the substance of the bills he wanted enacted. Then, often without even calling for a vote, he declared them approved and sent them to the full House or Senate for consideration.").

56. See SinDLER, supra note 3, at 92; see also id. ("The Long forces could meet that modest requirement even in the face of considerable absenteeism ....”).

57. See BRINKLEY, supra note 5, at 28 ("The clerk would mumble a few words of a bill; Long, standing just below the podium and bellowing instructions at his floor leaders, would call for a vote; and the legislators, often not even knowing what they were voting for, would dutifully pass it.”). 
Journalists observing these proceedings were horrified at the spectacle of an American legislature following orders like a flock of sheep and passing bills at the rate of one every few minutes. ${ }^{58}$ One contemporary commentator stated that "[t]he legislature meets, it pretends to initiate and enact laws, to scrutinize and debate them, and yet the operation has no more merit than it would have if these men moved in hypnosis." ${ }^{\text {59 }}$ Long defended this diminution of minority rights (and debate, for that matter) within the legislature with a ringing endorsement of majority rule, arguing, "Down in Louisiana we have no dictatorship, but what I call a closer response to the will of the people." ${ }^{60} \mathrm{He}$ added that "[a] perfect democracy can come close to looking like a dictatorship, a democracy in which the people are so satisfied they have no complaint." ${ }^{, 61}$ Legislators with complaints were out of luck.

\section{b. Eviscerating the Courts}

Consistent with his view that genuine democracy was harmed by separation of powers and minority rights, Long also sought to end meaningful judicial review of the legislature's work. Because Louisiana had an elected judiciary, this was not a difficult task. ${ }^{62}$ With the same tenacity that marked his own campaigns, the Kingfish backed judicial candidates that would support his policies without hesitation.

58. See HAIR, supra note 7, at 301 (stating that at one special session thirty-two bills passed in thirty minutes, with only their titles being read); SCHLESINGER, supra note 7, at 58 ("The legislature was wholly under Long's domination. Once it shouted through forty-four bills in twenty-two minutes."); see also F. Raymond Daniell, Once More Huey Long Calls the Dance, N.Y. TIMES, Sept. 2, 1934, at SM3 ("Thousands of words of description would be inadequate to depict the Huey P. Long who in five short legislative days recently transformed his State from a democracy to a potential military dictatorship.").

59. SwING, supra note 9, at 71 ; see id. at 70 ("[T]hirty-five bills were acted on in seventy minutes, thirty-four approved, one shelved. This was the pace . . . so long as Huey's machine holds together. Two minutes for a law; this is dictatorship."); see also KANE, supra note 4, at 129 ("The Reichstag of the Nazis did what it was told. Huey's Reichstag did not know what it was doing when it did it, and had to ask afterward if it wanted to find out.").

60. Russell Owen, Huey Long Gives His View of Dictators, N.Y. TiMEs, Feb. 10, 1935, at SM3.

61. WiLliAMS, supra note 5, at 762 (quoting an interview that Long gave to the New York World Telegram). Thus, while Long's critics were invoking the rhetoric of Montesquieu, see supra note 53, the Senator replied with a modern version of Rousseau's idea of the "general will." See Jean-Jacques Rousseau, Of the Social Contract, in THE SOCIAL Contract and Other Later Political Writings 39, 58 (Victor Gourevitch trans. \& ed., Cambridge Univ. Press 1997) (1762).

62. See CORTNER, supra note 16, at 108. For more on the origins of the elective judiciary in the United States, see Gerard N. Magliocca, ANDREW JACKSON AND THE CONSTitution: The Rise AND FALl OF GENERATIONAL REGimes 12, 77-78 (2007). 
Even before his gubernatorial term was over, the machine commanded a four-to-three majority on the Louisiana Supreme Court. ${ }^{63}$ This is why Time Magazine concluded in 1935 that "a legal test of the Senator's autocracy [was] out of the question.".64

Not content with this functional diminution of an independent judiciary, the Kingfish added new restrictions on the formal scope of judicial review. ${ }^{65}$ Perhaps the most notable of these was a statute that barred courts from issuing a remedy in cases involving the use of the National Guard, which allowed the Governor to invoke martial law at his discretion. ${ }^{66}$ Furthermore, courts were barred from examining the actions of voters' registrars, which gave the machine free reign to engage in fraud. ${ }^{67}$ And if that were not enough, the legislature also gave the Governor the power to issue unreviewable pardons, even for contempt of court, which drastically undercut the ability of any judges

63. See Carter \& Smith, supra note 11, at 12 ("The State Supreme Court, his by a consistent four-to-three margin, can legalize anything he has enacted ...."); Daniell, supra note 53 ("At the last election he gained control of the Supreme Court of the State, which now stands four to three in favor of any law he might conceivably cause the Legislature to adopt."). A superb article could be written about the state supreme court of this period. See SINDLER, supra note 3, at 94 ("The factional alignment within the highest state court - and it can be called little else - remained firm during this period when Long adhered to the forms of constitutionalism while perverting its substance.”). One issue is the reasoning of the proLong majority, which was justifying predetermined results in cases that were important to the machine. See White, supra note 6, at 252 (stating that Long "ordered the state Supreme Court, now stacked with John Fournet and other loyalists, to overrule decisions he did not like"). On the other side, there is a lot to explore about the behavior of the dissenters who were getting steamrolled by the Kingfish. See, e.g., State ex rel. Porterie v. Smith, 166 So. 72, 90 (La. 1935) (O’Niell, C.J., dissenting) (stating that the Constitution must bar Long's takeover of Baton Rouge's local government to ensure "that the government of Louisiana shall remain always and in truth a government of laws and not of men").

64. Political Note: Share-the-Wealth Wave, supra note 49, at 15; see SCHLESINGER, supra note 7, at 59 ("[T]he Kingfish's Supreme Court certified the constitutionality of his program. Every man was a king, but only one wore a crown.”).

65. As noted earlier, the Bureau of Criminal Identification was authorized to arrest suspects without a warrant, which also eliminated judicial oversight in that important area. See supra text accompanying note 14.

66. See Act of Aug. 20, 1934, No. 8, §§ 70, 76A, 1934 La. Acts Extra. Sess. 26, 30 31; WiLliams, supra note 5, at 726 ("One measure would authorize the governor to call out the militia merely at his discretion, not solely to repress riot or insurrection; it would also prohibit any court from issuing writs to restrain the governor in his use of the militia.'); Hermann B. Deutsch, Prelude to a Heterocrat: The Evolution of Huey Long, SATURDAY EvEnING Post, Sept. 7, 1935, at 5, 5 ("[T] he governor of Louisiana now has the right at his pleasure to call out the militia and put your community under martial rule... The law which authorizes it further prohibits the courts from so much as inquiring into the reasons prompting the governor in summoning the soldiery to active duty.").

67. See Letter from J. Edgar Hoover to Marvin H. McIntyre, supra note 14, at 2 (stating that a bill was passed barring court interference with "registrar of voters' activities"); see also WHITE, supra note 6, at 252 (observing that Long "took from the courts any power to adjudicate election disputes or to oversee registrars"). 
with backbone to curb abuses of power. ${ }^{68}$ Even the Ku Klux Klan, not exactly known for its defense of civil liberties, denounced these limitations as "un-American" because of its "knowledge of the necessity for the preservation of the courts and their vital importance to constitutional government. ${ }^{, 69}$

Finally, the Kingfish made an unprecedented effort to strong-arm the legal profession into turning down cases that challenged his regime. In 1934, the legislature created a new bar association that was controlled by the executive branch. ${ }^{70}$ Because attorneys could not practice in Louisiana without being a member, Long could blackball any lawyer who took a case he did not like. ${ }^{71}$ A newspaper editorial painted an ominous picture of what dissenters in Louisiana faced:

Louisiana is Huey Long's personal property. ... Y You will suddenly discover that you have violated a law. It does not make any difference whether you violated it or not, you are thrown in the jail house by a Long policeman, for Long has the power of hiring and firing all police officers in the state. You may ask for a lawyer, ... but it is mighty difficult to secure the services of a lawyer in Louisiana, if the lawyer knows that Huey is against you, for Huey also runs the bar association, and lawyers who become obstreperous find themselves disbarred. ${ }^{72}$

By packing the judiciary with his cronies, cutting off access to the courts on crucial issues, and making it extraordinarily difficult for litigants to find lawyers who would take on the state, Long dealt a serious blow to the rule of law.

68. See Act of Aug. 20, 1934, No. 14, § 2, 1934 La. Acts Extra. Sess. 45, 46; KANE, supra note 4, at 107 ("The Governor was given undisputed authority to issue reprieves to convicted men, and this power was extended to contempt cases - assurance to Long men that they could defy judges and get away with it."); Carter, supra note 51, at 361-62 ("A thug, making a premeditated skull-crushing attack upon a Long opponent, could draw from his pocket in court a pre-signed pardon from the figurehead Governor.").

69. Klan Declared Fighting Long, N.Y. HerALD TRIB., Aug. 17, 1934, at 6 (quoting Imperial Wizard Hiram W. Evans).

70. See Act of Nov. 21, 1934, No. 10, 1934 La. Acts 2d Extra. Sess. 162; SindLER, supra note 3, at 93 ("When the Louisiana Bar Association sought to bring disbarment proceedings against Attorney General Porterie ... Huey retaliated by creating a State Bar of Louisiana, headed by the Attorney General."').

71. See WHITE, supra note 6, at 252 (quoting an attorney who said that "[i]f a lawyer takes a case too obnoxious to Long, he will be walking the street in a week"); Carter \& Smith, supra note 11, at 12 (stating that Long "can decide, through his own state bar association, created by the legislature, who shall and who shall not be a ... member of the Louisiana bar"). The American Bar Association refused to recognize this group "on the ground that they represented a political and not a representative professional body." THOMAS O. HARRIS, THE KINGFISH - HuEY P. LONG, DiCTATOR 190 (1938).

72. Editorial, Huey Long and South Dakota, EvenING Huronite, Jan. 21, 1935, at 4. 


\section{c. Controlling the Election Machinery}

While the Senator was a proponent of untrammeled majority rule, he was just as interested in perpetuating his majority by fixing the system of vote counting. Graduating from the chicanery that is common for political bosses, Long simply put the administration of elections in the hands of his loyalists. ${ }^{73}$ For instance, custody of ballot boxes was taken from local sheriffs and given to election supervisors appointed by the Governor. ${ }^{74}$ Likewise, the selection of poll watchers was taken from the parishes (counties) and turned into patronage. ${ }^{75}$ The Saturday Evening Post explained: "[O]nly the faction in powerwhich is the Huey Long machine - shall henceforth have anything to do with handling, receiving or counting ballots. Louisiana is not merely an authoritarian state. It is 'the' authoritarian state."76

Naturally, the Senator's transformation of how elections were conducted was controversial. Long argued that he was expanding suffrage by abolishing the poll tax, asking, "Did you ever hear of a dictator that widened the base of the suffrage in his State? . . . I made it possible for three hundred thousand more people in my State to go to the polls." ${ }^{\text {"77 }}$ Mason Spencer, an anti-Long legislator, denounced the takeover of elections by the state and held that "the right to vote means the right to count the vote., ${ }^{, 78}$ Asserting that the Kingfish was "disenfranchis[ing] the white people of Louisiana," Spencer ended his speech against Long's last election bill on this prophetic note:

73. See Political Note: Share-the-Wealth Wave, supra note 49, at 15 ("The State's election machinery is so rigged that an outsider can never win."); Letter from J. Edgar Hoover to Marvin McIntyre, supra note 14, at 2 (noting that the special session passed "[a] bill increasing and enlarging the Governor's control of election machinery and officials").

74. See WHITE, supra note 6, at 202. While it was illegal to falsify election returns in Louisiana, the legislature refused to provide a penalty for that offense, which gave Long carte blanche to manipulate the count. See HaIR, supra note 7, at 250 (quoting a historian who said that "fixing elections became a crime for which there was no punishment").

75. See CORTNER, supra note 16, at 153 ("Supervisors of elections were created in each parish, two out of three of whom were to be appointed by the governor, and they were empowered to select the election commissioners and poll watchers in each parish."); SCHLESINGER, supra note 7, at 59 ("To insure against an uprising at the polls, the state government had exclusive authority to name all election commissioners; this enabled the machine to count the votes.").

76. Deutsch, supra note 66 , at 6 . This was especially true given that there was no longer any judicial scrutiny over many activities by election officials. See supra text accompanying note 67.

77. Forrest Davis, Huey Long: A Candid Biography, as reprinted in HuEY Long 79, 80 (Hugh Davis Graham ed., 1970).

78. CORTNER, supra note 16 , at 154 . Spencer is also quoted as saying, "The great leader walks among us and there are shouts of 'Hail Caesar.' I am not one who shouts 'Hail Caesar' because I have read history and know what happened to Caesar." Id. 
I am not gifted with second sight. Nor did I see a spot of blood on the moon last night. But I can see blood on the polished floor of this Capitol. For if you ride this thing through, you will travel with the white horse of death. White men have ever made poor slaves. ${ }^{79}$

With the Senator in control of the ballot, Long's opponents began to wonder whether their only salvation was the bullet. ${ }^{80}$

\section{Quashing Resistance by Force}

The Kingfish was adept at manipulating institutions and procedures to insulate his regime from accountability, but he also took more direct steps to eliminate dissent. These substantive tactics included (1) placing limitations on expression, (2) using the instrumentalities of municipal government to punish foes, and (3) invoking martial law. When combined with his grip on state power, Long's actions led to cries of dictatorship and rumblings of armed rebellion. ${ }^{81}$

\section{a. Free Press Under Attack}

Some of the Senator's harshest critics were in the local media, and the Kingfish retaliated with discriminatory taxes and the coercive use of state contracts. In 1934, the legislature passed an advertising tax on papers with a large circulation, which happened to be in cities where antipathy for Long was intense. ${ }^{82}$ Defending this act, he said, "I believe in freedom of speech, but it's got to be truthful speech, and lying newspapers should have to pay for their lying. I'm going to help these newspapers by hitting them in their pocketbooks; maybe then

79. Carter, supra note 51, at 343. Of course, nobody cared much about the disenfranchisement of African-Americans. Cf. WILLIAMS, supra note 5, at 850 ("As Spencer returned to his seat, the galleries broke into loud applause, moved either by his defense of local liberty or of white superiority.").

80. This line is inspired by "a ballot or a bullet," which was a slogan made famous by Malcolm X. See Malcolm X, The Ballot or the Bullet, Speech at the Cory Methodist Church (Apr. 3, 1964), in Malcolm X Speaks: Selected Speeches and Statements 23, 30 (George Breitman ed., Pathfinder Press 2d ed. 1989) (1965).

81. See, e.g., HAIR, supra note 7, at 280 (quoting one editorial stating that "the time has arrived to take down the old musket from over the door, give it a good greasing and be prepared to march on Baton Rouge").

82. See Act of July 12, 1934, No. 23, 1934 La. Acts 176; HAIR, supra note 7, at 279 (explaining that the act "levied a 2 percent tax on the advertising income of newspapers in Louisiana with circulations of more than twenty thousand"); WHITE, supra note 6, at 213 ("The tax affected only the dailies in New Orleans and other urban centers, and of those papers, only [one] was not rabidly anti-Long."). 
they'll try to clean up." ${ }^{93}$ The American Newspaper Publishers' Association rejected his position and said that if the Senator was not stopped, "he would Hitlerize the state and nation." "\$4 Meanwhile, small, rural papers faced a new state printing board that assessed whether they would get contracts to print official records. ${ }^{85}$ Hodding Carter, a leading anti-Long editor, explained that the right to publish local minutes, tax delinquent lists, ordinances, and court notices was worth thousands of dollars and "meant the difference between survival and failure." 86 Papers fearful of losing their contracts often stopped covering politics entirely lest they offend the Senator. ${ }^{87}$

While Long could not control what journalists outside of the state said about him, he found a way to shape their message inside Louisiana. In 1935, the Kingfish saw a critical newsreel and decided to create a State Board of Censors. ${ }^{88}$ This Orwellian agency had the power to review and edit all movies shown in the state, presumably to delete any negative coverage of the Senator. ${ }^{89}$ Though it does not appear that this censorship board did anything prior to Long's death, its

83. CORTNER, supra note 16, at 67; see WHITE, supra note 6, at 214 ("[One representative] responded that 'the only purpose of this tax is to warn every paper in the state, large and small, to line up and stop criticizing the administration or they will suffer a similar fate."').

84. CORTNER, supra note 16, at 91. Comparisons between Long and Hitler were rife in 1934 and 1935. See Corey Ford, Heil Huey!, VANITY FAIR, May 1935, at 13, 13; see also CORTNER, supra note 16, at 149 ("Huey Long was a Hitler in every sense but one. Hitler controls the press of Germany. Huey Long did not control the press of Louisiana ...." (quoting a Chicago Tribune editorial)); Martin Sommers, Caesar or Hitler? History Will Decide, Daily OKLAHOMan, Sept. 11, 1935, at 1 ("[T] he rest of the nation considered the senator a baby Hitler ... headed for a dictatorship the like of which the United States has never experienced."). This marks the start of the ad Hitlerum argument in constitutional law, and it is intriguing that this line of thought developed so soon after the Nazis' rise to power.

85. See HAIR, supra note 7, at 301 ("This agency, its members all appointed by the governor, would solely determine which newspapers were eligible to be 'the official printer' for governmental subdivisions in Louisiana, including parishes, municipalities, and school boards."); Deutsch, supra note 66, at 5 ("A recently created state printing board is authorized to veto any contract awarded for public printing, should such a contract be awarded to an antiLong paper, even though the journal be published in an anti-Long community.").

86. Carter, supra note 51, at 356.

87. See CORTNER, supra note 16 , at 96 .

88. See White, supra note 6, at 237. One of these newsreels called Long "the dictator of Louisiana" and said that he was "making many Americans regret that the United States ever purchased Louisiana." See HuEY LONG (RKB/Florentine Films 1985) (showing this footage in a documentary by Ken Burns).

89. See Act of July 8, 1935, No. 16, 1935 La. Acts 3d Extra. Sess. 40; CorTnER, supra note 16, at 96; see also HAIR, supra note 7, at 305 ("[L]ocal governments were specifically forbidden to approve or disapprove of films (twenty-eight representatives and four senators voted against this bill, the highest nay vote recorded at the session)."). 
mere existence demonstrated the lengths to which the Kingfish would go to undermine the normal practices of democracy.

\section{b. Local Government and Political Vengeance}

When local government became the only sanctuary for dissent in Louisiana, Long rammed through a series of bills that transferred most municipal employment and power to the state. ${ }^{90}$ By 1935 , the hiring of almost all parish and town employees, including policemen, teachers, and firemen was placed in the hands of the Governor. ${ }^{91}$ The attorney general was also given the authority to supersede any local district attorney, which protected the regime against any indictments or investigations that might be embarrassing. ${ }^{92}$ When local elected officials became a thorn in the Kingfish's side, he sometimes simply abolished their offices or their town's autonomy. ${ }^{93}$

More important, by capturing the regulatory authority of local government, Long acquired a new set of means to make life difficult for his critics. For example, the state wielded the power to change property assessments (and taxes) for people who refused to toe the line. ${ }^{94}$ State bank examiners and dock inspectors harassed dissidents

90. Long's annihilation of municipal government is an interesting feature of this era, because a right to self-government below the state level is not a part of our constitutional tradition. Compare State ex rel. Porterie v. Smith, 166 So. 72, 84 (La. 1935) (O’Niell, C.J., dissenting) ("The all-important question in this case is whether the Constitution of Louisiana permits the Legislature to enact a special or local law taking away from the people of one parish - and only one parish - their right of local self-government ...."), with id. at 92 (per curiam) (petition for rehearing) ("We know of no provision in the Constitution, nor has any been pointed out to us, which gives a municipality or parish, which are subdivisions of the state, created by the state Legislature, a right superior to the sovereign state to govern the people within their territorial limits.").

91. See SCHLESINGER, supra note 7, at 59 ("No municipal officer-policeman or fireman or schoolteacher-could hold his job except by Long's favor.'); SINDLER, supra note 3 , at 93 (noting that this even extended to bus drivers and janitors).

92. See WHITE, supra note 6, at 252; see also SINDLER, supra note 3, at 94 (noting that there was no judicial review of a decision by the Attorney General to supersede a district attorney).

93. See KANE, supra note 4, at 112 (describing Long's abolition of the town of Alexandria). In Baton Rouge, Long doubled the size of the "police jury," which was essentially the city council, and made the new seats state appointees. See Williams, supra note 5, at 785-86 (describing the Long takeover). Compare Porterie, 166 So. at 85 (O'Niell, C.J., dissenting) (rejecting this act and stating that "constitutional limitations, or guaranties, are intended to protect minorities of the people" and that "[t]he majorities can protect themselves"), with id. at 93 (per curiam) (petition for rehearing) ("There is nothing before this court to show that the constitutional rights of a minority of the citizens are being transgressed by an aggressive majority ....”).

94. See KANE, supra note 4, at 108 ("The Governor now had the power, through his stooges, to raise or to lower the assessment on any piece of property in the state - and to make the change retroactive for three years."); Carter, supra note 51, at 355 ("The State Tax 
by denying them credit or refusing to let their cargo land. ${ }^{95}$ And anyone who needed a municipal business license had to bow to the Kingfish or provide kickbacks to his machine. ${ }^{96}$ It was corruption on a massive scale that turned almost all governmental functions of the state into a test of political loyalty.

\section{c. The Beginning of a Police State}

With feelings running high and threatening to spill onto the streets, Long reached for the ultimate weapon in the dictator's do-ityourself kit - the use of armed troops and police to crush protests. In addition to his powerful state police force, the Kingfish came up with the idea of "partial martial law," which allowed him to suspend the Constitution even when there was no military necessity. ${ }^{97}$ For instance, the Senator ordered the National Guard into New Orleans shortly before the primary in 1934 to guarantee "security" for the elections." The Kingfish's opponents responded by forming a militia called the Square Deal Association, which drilled openly and called for an uprising against the regime. ${ }^{99}$ In January 1935, armed Square Dealers

Commission was given the right to change any city or county tax assessment, so that a misbehaving corporation or individual might know just who held the economic stranglehold.")

95. See WhITE, supra note 6, at 253.

96. See SINDLER, supra note 3, at 92.

97. See HAIR, supra note 7 , at 280 . The BCI, which already had considerable power, was augmented in 1934, and the identity of its members became a state secret. See HaIR, supra note 7, at 281 ("The number and names of its rank-and-file members were known only to Long's inner circle ...."); SINDLER, supra note 3, at 94 ("The governor also was empowered to increase, without stated limit, the personnel of the State Bureau of Identification, more familiarly known in Louisiana as Huey's Cossacks.”).

During World War II, a federal court reviewing the declaration of martial law in Hawaii explained that military necessity was a requirement for such an action even though " $[\mathrm{t}]$ here is a pernicious doctrine known as 'partial martial law', which was developed by an ambitious governor as a method of dictating regulations to the people of a state uncontrolled by the Constitution or laws thereof.' United States v. Minoru Yasui, 48 F. Supp. 40, 49-50, 50 n.26 (D. Or. 1942), vacated, 320 U.S. 115 (1943) (mentioning "Governor Allen of Louisiana acting under express directions of Senator Huey Long").

98. See WHITE, supra note 6, at 208 ("As his national guardsmen surrounded City Hall, he ordered Governor Allen to declare martial law throughout the city. Soon after, he had the state's remaining 2,500 national guardsmen brought by train from garrisons across the state.”); WILLIAMS, supra note 5, at 722-23 (describing the background of this incident).

99. See Martial Law, supra note 14 (noting "the surrender of 100 citizens who had hastily taken up shotguns, pistols and sporting rifles at the call of the Square Deal Association, sworn to destroy the dictatorship of Senator Huey P. Long"). The Square Deal Association sent a telegram to Governor Allen stating, "We as individuals and as an organization will not tolerate practices which deny us, as free citizens, government of the people, for the people and by the people." HARRIS, supra note 71, at 198; see also WILLIAMS, supra note 5, at 784-85 (tracing the birth of the Square Deal Association). 
stormed the courthouse in Baton Rouge and clashed with Long's troops at the airport. ${ }^{100}$ The Senator answered with a martial law proclamation in Baton Rouge that banned criticism of the state, possession of guns, and any public gathering of two or more people, which one historian calls "unusually stringent in the history of American martial law."101

Now desperate for help, the oppressed citizens of the state turned to their only hope - the federal government. Telegrams poured into the White House urging the President to federalize the National Guard. ${ }^{102}$ One said, "[Long's acts] will inevitably mean a civil war in Louisiana. The only possible chance of averting this calamity is for the National Guard to be drafted into federal service during the period of this emergency."103 Another stated, "Baton Rouge, seized by Long, is under martial law, men in defense of their rights are arriving from all the parishes .... The mothers of Baton Rouge earnestly appeal to you to take immediate steps to prevent further bloodshed." ${ }^{104}$ It was clear that Huey Long and his ambition presented a national problem.

\section{The SLEEPING GIANT AWAKENS}

This Part examines the conflict between the Kingfish and the federal government, which eventually centered on the question of whether Louisiana was violating the Guarantee Clause. ${ }^{105}$ While that

100. See White, supra note 6, at 226-27.

101. WILliAMS, supra note 5, at 787; see HAIR, supra note 7, at 299 (explaining that Baton Rouge became the First Military District). There are some fascinating Second Amendment implications in this episode. When advocates of individual gun rights claim that an armed citizenry is necessary to stop local tyranny, Huey Long's Louisiana should be their leading example. Moreover, the Senator tried to restrict the ownership of firearms in a bill introduced in the state legislature a few days before he was assassinated. See WHITE, supra note 6, at 261 ("One bill revealed his fear of violent uprising and required the registration of rifles, sawed-off shotguns, and gas grenades with the BCI.").

102. See, e.g., Telegram from C.C. Roy, Vice Chairman, Square Deal Ass'n of Avoyelles Parish, La., to Franklin D. Roosevelt (Jan 26, 1935) (on file with the FDR Library) ("The personnel of the National Guard in this state is in tremendous danger as long as the destinies are in the hands of the present authorities the only hope of averting this bloodshed is for the Federal Government to take over the Louisiana National Guard."); Telegram from Mrs. Horace Wilkinson to Franklin D. Roosevelt (Jan. 26, 1935) (on file with the FDR Library) ("Governor O.K. Allen, acting under Huey P. Long's order has ordered out the state militia. ... Do help us to destroy Huey's power.”).

103. Telegram from Vernon R. Mayer to Franklin D. Roosevelt (Jan. 26, 1935) (on file with the FDR Library).

104. Telegram from Mrs. J.A. Tucket, Chairman, Baton Rouge Mothers, to Franklin D. Roosevelt (Jan. 26, 1935) (on file with the FDR Library).

105. The title of this Part refers to a quote by Senator Charles Sumner that described the Guarantee Clause. See Cong. Globe, 40th Cong., 1st Sess. 614 (1867) (statement of Sen. Sumner) ("It is a clause which is like a sleeping giant in the Constitution, never until this 
was an issue of great importance to lawyers, the ensuing discussion cannot be understood unless it is seen in the context of Long's national popularity that threatened FDR's reelection in $1936 .^{106}$ Two master politicians were at work, but, ironically enough, it was popular opinion, rather than legal elites, that pushed the President into seeing the Guarantee Clause as a way to challenge Long's dictatorship. ${ }^{107}$

\section{A. The Patrician versus the Populist}

When Long assumed his vacant Senate seat, he quickly became the bane of the party establishment. The Kingfish supported FDR's nomination in 1932, but he soon emerged as the leading liberal critic of the New Deal, lashing the President's agenda in long and colorful filibusters on the Senate floor. ${ }^{108}$ Whether Long's stance rested on genuine feeling or sheer opportunism, FDR soon concluded that the Senator could not be turned around and responded by denying him federal patronage. ${ }^{109}$ Long answered by enacting a state statute that made it a crime to use federal funds for "political" purposes and by threatening to file suit in the United States Supreme Court's original jurisdiction, claiming that FDR's policy infringed the Tenth Amendment. ${ }^{110}$

recent war awakened, but now it comes forward with a giant's power... . There is no clause which gives to Congress such supreme power over the States ....").

106. In other words, FDR probably would not have done anything about the regime in Louisiana but for Huey Long's presidential challenge.

107. It is worth noting that a Guarantee Clause challenge was made in state court based on Long's attack on local government in Louisiana. See State ex rel. Porterie v. Smith, 166 So. 72, 82 (La. 1935). The Louisiana Supreme Court held that this claim was not justiciable and commented that "it is settled jurisprudence that the guarantee in the Federal Constitution to the states of a Republican form of government does not extend to the systems of local government for the municipalities, counties, and parishes of a state." Id.; see id. ("[T]he question whether this constitutional guarantee has been violated is not a judicial but a political question, committed to Congress, and not to the courts.").

108. See SCHLESINGER, supra note 7, at 53 (stating that "Long played an important role in holding southern support for Roosevelt" at the Democratic Convention); WHITE, supra note 6, at 182-83 (documenting Long's criticisms of the legislation introduced during FDR's "Hundred Days"); see also WiLliams, supra note 5, at 832-35 (describing Long's filibuster of the National Recovery Act).

109. See HAIR, supra note 7, at 285 ("When Senator Long and the president first fell out, early in 1933, the White House merely denied him patronage."); WHITE, supra note 6, at 181 ("Soon though, Roosevelt administrators consulted only with anti-Long leaders . . . when awarding federal jobs.").

110. See KAnE, supra note 4, at 127 ("At a time when other states were scrambling for Federal funds, Huey took steps to keep them out of Louisiana. ... A companion measure set up state supervision of any and all expenditures of funds or credits obtained from the Federal Government."); Legislature Ready for New Long Bills, supra note 53 (describing a bill that "would make it a criminal offense for any person to use any Federal relief money for 
Meanwhile, Long was busy building an independent national organization that could support his presidential bid. The Share Our Wealth movement argued that the solution to the Depression was a wholesale redistribution of income - an idea that one historian calls "a product of political craftsmanship by a skilled artisan who had been intermittently at work on his masterpiece since 1918." the simplicity of this proposal, voters across the nation rushed to establish Share Our Wealth clubs, and by 1935 they had more than four million members. ${ }^{12}$ At no cost, members got a copy of Long's autobiography, Every Man A King, a subscription to his paper, American Progress, and copies of his Senate speeches. ${ }^{113}$ Soon Long was getting more letters than all of the other Senators combined. ${ }^{114}$

The President and his advisors grew increasingly nervous as Long ramped up his national campaign. While FDR was confident that Democrats would not nominate the Kingfish in 1936, he was not so sure about the result of a third-party challenge. A secret poll done by the Democratic National Committee found that Long would get at least eleven percent of the popular vote (plus the electoral votes of Louisiana), which could swing the election to the GOP. ${ }^{115}$ This was, in fact, the Senator's strategy. He told his aides that if he could split the liberal vote and elect a Republican, then the path would be clear for him to take the Presidency in $1940 .{ }^{116}$ To ensure that he would have

'political' purposes" and stating that "Mr. Long explained to reporters that the bill dealing with Federal funds was designed to 'aid' President Roosevelt"); see also 79 CONG. REC. 11,453 (1935) (statement of Sen. Long).

111. SinDLER, supra note 3, at 84; see WilliAMS, supra note 5, at 692-97 (outlining the platform of the Share Our Wealth movement that Long announced in a radio address on February 23, 1934).

112. See Williams, supra note 5, at 700-01 (noting also that Long claimed he had over seven million members even though that was not supported by his records).

113. See SindLER, supra note 3, at 85; see also WHITE, supra note 6, at 198 ("He ordered that the Share Our Wealth clubs collect no dues from members. This allowed the poor to join ....”).

114. See White, supra note 6, at 198; see also Williams, supra note 5, at 698 ("By April 1935 his office was receiving an average of 60,000 letters a week, and in one week alone it was deluged with 140,000 letters.").

115. See HAIR, supra note 7, at 307 (stating that DNC Chairman James Farley believed that Long held "the balance of power in the 1936 election"); KANE, supra note 4, at 126 ("As Farley prepared for 1936, he reveal[ed] ... '[Long's] probable support was not confined to Louisiana and nearby states. On the contrary, he had about as much following in the North as in the South, and he had as strong an appeal in the industrial centers as he did in the rural areas."').

116. See WiLliams, supra note 5, at 843-44 (describing Long's plan to gather attention by challenging FDR in the Democratic Convention before launching a Share Our Wealth party). The harsh premise of Long's plan was that the GOP would exacerbate the Depression and make it easier for a redistribution platform to sweep the country. See WHITE, supra note 
plenty of time to run in 1936, Long moved the state primary up to January so that he would be safely reelected to his Senate seat before the fall campaign began. ${ }^{117}$

While the President tried to undercut this threat by proposing new taxes on the wealthy, he also showed that Long was not the only one who could play rough. ${ }^{118}$ J. Edgar Hoover put the Senator under surveillance and sent his reports directly to the White House. ${ }^{119}$ The IRS was ordered to investigate the Kingfish and to put the man who took down Al Capone in charge of the tax case. ${ }^{120}$ FDR even persuaded a former Texas governor to head the prosecution team, but getting a conviction against Long was a tall order. ${ }^{121}$ Indeed, the prosecutor told an aide, "We are not going to convict Huey Long before a Louisiana jury by proving he cheated on his income tax.... We might embarrass him, but he embarrasses hard." ${ }^{22}$ The President needed another approach to stop the Kingfish's bandwagon.

\section{B. Popular Constitutionalism in Action}

While Long and FDR were engaged in their high-stakes duel, a more basic conversation was going on about whether the Guarantee Clause applied to the Louisiana situation. What is interesting about this dialogue is that activists and journalists, not lawyers or scholars, were the ones pushing for this constitutional action. Eventually, this popular chorus about the need to restore republican government got the attention of the President.

6, at 242 ("He saw nothing wrong with letting the nation suffer for four miserable years in order to demonstrate that the country needed him as president.").

117. See HAIR, supra note 7, at 317; KANE, supra note 4, at 125.

118. See HAIR, supra note 7, at 307 ("Roosevelt's most adroit response to the Kingfish was his sponsorship of the Wealth Tax Act of 1935, which sharply raised federal income taxes at the top levels."); WilliaMS, supra note 5, at 812 ("One night in the spring [of 1935], while discussing with a few close associates the evidence of Huey's spreading influence, Roosevelt startled them by saying that he might have to take over as his own some of Long's ideas in order to, as he put it, 'steal Long's thunder."').

119. See WHITE, supra note 6, at 217 (describing Hoover's request that the agent in charge for New Orleans provide a daily report on Long, "including political information, because the daily reports were required by a "confidential source"').

120. See WHITE, supra note 6, at 163 (describing the background of the lead investigator); WILLIAMS, supra note 5, at 796-97 (noting that a tax inquiry was undertaken during the Hoover Administration but was dropped).

121. See WiLliams, supra note 5, at 797.

122. HAIR, supra note 7, at 287. A recent biography of Long states that federal prosecutors decided a few days before the assassination to present their case to a grand jury. See WhITE, supra note 6, at 224. 
As the Kingfish ran roughshod over state institutions, his critics argued that the conditions necessary to trigger the Guarantee Clause were at hand. The Women's Committee of Louisiana, an anti-Long grassroots organization, was the first to make this point when they informed the New York Times that the "[w]omen of Louisiana [had] watched their State lose a republican form of government through Senator Long's corrupt political machine."123 To drive this message home, they petitioned Congress for assistance, stating, "[T]he ballot box is no longer a medium for the expression of the will of a people and a republican form of government no longer exists for a State of this Union." ${ }^{24}$ Newspaper editorials quickly picked up on this sentiment, ${ }^{125}$ and the Detroit Free Press gave its readers this summary of the relevant law:

The Constitution of the United States guarantees to Louisiana a republican form of government, which implies free and honest election of State officials. This guarantee was appealed to by the authorities of Rhode Island at the time of the Dorr rebellion. Grover Cleveland did not wait for an invitation to implement it in 1894, when the railway strike in Chicago disrupted the processes of government.

... The delicate question of State sovereignty is involved, as well as National pride. Administrations in Washington hesitate to humiliate States of the American Union by sending troops into them to maintain law and order and supervise elections .... ${ }^{126}$

When the Mayor of New Orleans asked for federal intervention in August 1934, though, the Justice Department concluded, "[T]here is no legal warrant for the Mayor's suggestion .... There has been no application by the Legislature or the Governor, and there appears no imminent danger of interference with Federal functions or property or of deprivation of constitutional rights."

123. See Hilda Phelps Hammond, Letter to the Editor, Louisiana Women Protest, N.Y. TIMES, Aug. 31, 1933, at 16. I cannot find any references to the Guarantee Clause or to a republican form of government in the national press prior to 1933, but there could be some that I missed.

124. Louisiana Women Assail Long Here, N.Y. Times, Jan. 9, 1934, at 23.

125. See, e.g., Long's Revolution, CHI. DAILY TRIB., Aug. 22, 1934, at 12 ("It is one of the federal government's responsibilities to insure to the people of every state a republican form of government, and Long has abolished it in Louisiana. We do not think the majority of the people of that state want to live under a dictatorship. It has been imposed upon them by violence.").

126. Editorial, supra note 13. For a discussion of the Guarantee Clause issue raised during the Pullman Strike of 1894, see Gerard N. Magliocca, Constitutional False Positives and the Populist Moment, 81 Notre Dame L. Rev. 821, 852 (2006).

127. Letter from Harold M. Stephens, Acting Att'y Gen., to Louis McHenry Howe, Sec'y to the President 4 (Aug. 8, 1934) (on file with the FDR Library). The Guarantee 
All of this public interest in the Guarantee Clause led a reporter to ask the President about this as the Department of Justice (DOJ) was considering the issue. Here is the transcript of the exchange that followed:

Q: May I get back to the Constitution for a moment. Have you given any thought to the possible connection between conditions in the State of Louisiana today and certain clauses in the Constitution which make it mandatory on the Federal Government to maintain a republican form of government in every state?

THE PRESIDENT: That's a new one - of course there again on this Louisiana situation, obviously we want to maintain a republican form of government, but at the same time, under the republican form of government, ... the Legislature of the State of Louisiana has the inherent, constitutional right to govern a municipality within that State as it sees fit, provided it does not violate the right of franchise and certain rights of self-government. That is about as far as you can go.

Q: Are you satisfied they have not violated those certain rights? ....

THE PRESIDENT: In the City of New Orleans?

Q: No, in the State.

THE PRESIDENT: I should say that if there was a free franchise in the State of Louisiana, the questions would come up as to whether a free franchise was being exercised or not, and we haven't gotten to that yet. Here's a nice point. Let me ask you a question. Is it a republican form of government for the State of Rhode Island to confine the franchise only to people who have a certain amount of property?

Q: They had a revision of that one time.

THE PRESIDENT: That's a nice question - there is a very restrictive franchise in the State of Rhode Island today.

Q: In other words the clause is all wide open.

THE PRESIDENT: No. $^{128}$

This fascinating colloquy was conducted at a high level of constitutional sophistication by the President and by his interlocutor. For example, both indicated that they were familiar with the main precedent on the Guarantee Clause, Luther v. Borden, which arose out

Clause states that the federal government shall protect states from domestic violence "on Application of the Legislature, or of the Executive (when the Legislature cannot be convened)." U.S. CONST. art. IV, § 4.

128. Press Conference No. 137 , in 4 COMPLETE Presidential Press CONFERENCES OF Franklin D. RoOSEVelt 17, 22-24 (1934) [hereinafter 4 PRess CONFERENCES] (emphasis added). 
of the civil strife that unfolded in Rhode Island during the $1840 \mathrm{~s}^{129}$ Furthermore, FDR distinguished the issue of local self-government, which probably did not implicate the Guarantee Clause, from the violation of basic rights. Yet the President did not commit to any course of action.

The drumbeat for invoking the Guarantee Clause only grew after the Senator declared martial law in Baton Rouge. For instance, a letter to the editor in the Philadelphia Record said, "Our Federal Constitution guarantees a republican system of government to all the States. Therefore, it is about time that President Roosevelt steps in to do his duty by the people of Louisiana." " Another journalist commented that the Kingfish "would do well to meditate upon Article IV, Section 4, of the Constitution." "131 And yet another wrote, "There remains no one to gainsay the will of the dictator, save possibly Uncle Sam, who under the Federal Constitution is charged with the duty of guaranteeing a republican form of government to each of the forty-eight States." ${ }^{\prime 32}$ Even more interesting were the messages arriving at the White House calling on the President to act and offering advice on how the Guarantee Clause issue should be handled. ${ }^{133}$ In one example, a letter to FDR quoted the Guarantee Clause and explained, "[I]t is common knowledge, confirmed daily by the press, that Senator Long has established a virtual dictatorship in Louisiana." 134 Given this state of affairs, the President could do three things:

1. The President might declare that Louisiana ... was no longer a state .... He then might order federal troops into the state, oust

129. See Luther v. Borden, 48 U.S. (7 How.) 1, 34-38 (1849) (discussing the Dorr Rebellion). This awareness was indicated by FDR's use of Rhode Island as an example in the text that I have italicized, which is otherwise inexplicable. The reporter's response that there was a "revision" involving the state confirms this interpretation.

130. Joseph Robles, Letter to the Editor, A Modern Don Quixote, PhILA. Rec., Jan. 22,1935 , at $8 \mathrm{C}$.

131. John Chamberlain, Books of the Times, N.Y. Times, Mar. 19, 1935, at 19.

132. Daniell, supra note 53; see Herbert Little, The Constitution and Huey, WASH. DAILY NEWS, Feb. 6, 1935, at 15 ("The Constitution's guarantee of a republican form of government, now sought to be invoked against Sen. Huey P. Long of Louisiana, was written to head off any possible American movements toward monarchy .....").

133. See, e.g., Letter from T.V. Wensel to Franklin D. Roosevelt (Jan. 28, 1935) (on file with the FDR Library) ("[A] republican form of government does not exist to-day in the State of Louisiana; the state capital (Baton Rouge) is to-day under martial law, this law invoked by Huey Long's puppet Govenor? [sic] Allen.'); Telegram from Val Irion, President, Young Democrats of La., to Franklin D. Roosevelt (Jan. 26, 1935) (on file with the University of Virginia Library) ("There is little semblance of republican government in Louisiana. An armed dictatorship is in control.”).

134. Letter from Benjamin L. Simmons to Franklin D. Roosevelt (July 13, 1935) (on file with the FDR Library). 
the usurpers, and proceed to reconstruct the state as was done with the southern states after the Civil War. This, however, is drastic and risky.

2. The President might, in a special message to Congress, present this argument and evidence to support it, and leave to Congress the duty of declaring the proper line of action.

3. The aggrieved people in Louisiana, Long's enemies, might be urged to appeal to the President and Congress on these grounds. ${ }^{135}$

This list neatly summarized the options and the risks that FDR faced in deciding whether to use the Guarantee Clause against Huey Long.

When the President was asked in a 1935 press conference about his thinking on Louisiana, he was rather evasive:

Q: Has there been any determination if there is a Republican form of government existing in Louisiana?

THE PRESIDENT: What kind of determination?

Q: Has there been any determination?

THE PRESIDENT: Well, that opens a wide field for speculative debate on a theoretical problem. Who shold [sic] make the determination?

Q: Well, the Constitution says something about it.

THE PRESIDENT: That does not say who makes the determination. (Laughter) $^{136}$

FDR did not tell the assembled reporters that he was ordering a new Justice Department inquiry into the Guarantee Clause question.

\section{Weighing the Merits of Federal Action}

Pushed by popular and media opinion, the President asked for a memo from his lawyers on the feasibility of destroying the Kingfish by claiming that Louisiana flunked minimal constitutional standards. The analysis produced was the most comprehensive public text on the Guarantee Clause ever written and framed the legal, though not the political, considerations that shaped FDR's subsequent thinking.

\section{Contents of the DOJ Memo}

The memo sent to the President by the Justice Department was clear that the Guarantee Clause raised a political question and that congressional participation was required in any decision on the lack of

135. Id.

136. Press Conference No. 176, in 5 COMPLete Presidential Press Conferences of FrANKLIN D. ROOSEVELT 58, 61 (1935). 
democracy in Louisiana. ${ }^{137}$ With respect to the courts, the memo reviewed the relevant precedents and concluded in no uncertain terms that " $[\mathrm{t}]$ he question whether a State is enjoying a republican form of government, does not present a justiciable controversy that may be determined by the courts, but is political in its nature."138 Second, " $[\mathrm{t}]$ he power to determine whether a republican form of government prevails in a State, is reposed in the Congress, which is also vested with authority to enforce the guaranty contained in Article IV, Section 4 of the Constitution." ${ }^{\text {"139 }}$ While the President could act unilaterally to protect federal property at risk in the state, "cooperation on the part of the Congress will be required, if it is desired to act under the constitutional provision guaranteeing to every State of the Union a republican form of government."

On the question of whether Long's actions violated the Constitution, the Justice Department strained to extract guidance from the limited set of authorities. Drawing on Madison's essay in The Federalist, the memo concluded that " $[\mathrm{t}]$ he distinguishing feature of a republican government is the right of the people to choose their own officers for governmental administration, and pass their own laws in virtue of the legislative power reposed in representative bodies., ${ }^{141}$ Unfortunately, the memo did not attempt to apply this standard to the Kingfish's seizure of the election machinery or his "streamlined" legislature procedures. Likewise, the memo said that "[a] military government, established as the permanent government of the State, would not be a republican form of government," ${ }^{, 142}$ and it conceded that the use of emergency power in Louisiana was "merely because of the whim and caprice of the Governor" rather than "a result of the

137. There were actually two memoranda delivered: one that summarized the analysis and another that provided a full discussion. See Memorandum from Alexander Holtzoff to the Att'y Gen. (Apr. 8, 1935) [hereinafter Second Holtzoff Memo] (giving the details).

138. Id. at 24 .

139. Id.

140. See Holtzoff Memo, supra note 18, at 3. This portion of the memo refers to a separate analysis on the use of the Commander-in-Chief authority that I have been unable to locate, even though it is described by at least one other source. See Letter from Harold M. Stephens, Assistant to the Att'y Gen., to Homer Cummings 6 (Sept. 7, 1935) (on file with the University of Virginia Library) ("[A] considerable time ago you had Mr. Holtzoff prepare a memorandum with reference to the use of Federal troops in the Louisiana situation, the powers of the President with regard to the constitutional guarantee of a Republican form of government, and the powers of the President to march the National Guard out of Louisiana or to withdraw from it its military equipment ....").

141. Second Holtzoff Memo, supra note 137, at 6-7 (quoting THE FEDERALIST No. 39 (James Madison))

142. Id. at 15 . 
existence of any riot or insurrection or inability on the part of the civilian authorities to enforce the law." ${ }^{143}$ The Justice Department expressed "grave doubt," though, that this was "in itself sufficient to justify a finding that the State of Louisiana [had] ceased to have a republican form of government" and said that "no light [seemed] to be thrown on it by the decided cases."

While the shortage of case law on a political question was not surprising, the real obstacle for a sound analysis of the crisis was the lack of a conceptual framework that could show when a state was in default on its fundamental obligations. In 1935, the web of doctrine that is typically described as part of the Lochner era was under attack by the New Deal. ${ }^{145}$ While there were aspects of Long's regime that impinged on property and contract rights, the Justice Department could hardly be expected to use these arguments against the Kingfish when they were trying to undermine those rights everywhere else. ${ }^{146}$ In a handful of decisions, the United States Supreme Court had started incorporating the Bill of Rights, but those cases were still tentative and did not have a unifying theme. ${ }^{147}$ With constitutional law in a state of flux, the challenge posed by Long took on added importance. A decision to use the Guarantee Clause would set a powerful precedent on how traditional legal principles should be read in light of the New Deal.

143. Id. at 10 .

144. Id. at 14. The memo expressed reservations because the declaration of martial law was "reviewable by Federal courts on the theory that if [the] action is not justified it constitutes a deprivation of due process of law within the meaning of the Fourteenth Amendment" and could be invalidated. Id. Accordingly, the DOJ suggested that the mere existence of a federal constitutional claim could defeat a Guarantee Clause argument.

145. See Lochner v. New York, 198 U.S. 45 (1905) (defining a period where the "liberty of contract" was a central organizing principle).

146. In a Lochnerian universe, a Guarantee Clause argument would emphasize Louisiana's use of economic coercion, whether that involved state contracts for newspapers, discriminatory taxes, patronage, or the arbitrary acts of municipal instrumentalities.

147. See Powell v. Alabama, 287 U.S. 45, 71 (1932) (holding that the right to counsel in a capital case was binding on the states); Near v. Minnesota ex rel. Olson, 283 U.S. 697, 707 (1931) ("It is no longer open to doubt that the liberty of the press, and of speech, is within the liberty safeguarded by the due process clause of the Fourteenth Amendment from invasion by state action.”). Even with respect to voting rights, where there was constitutional text on point, explaining why Louisiana was not republican posed a problem. Because African-Americans could not vote across the South, the memo had to say that "[a] republican form of government does not imply a government in which necessarily all citizens are granted the right of suffrage." Second Holtzoff Memo, supra note 137, at 15. 


\section{Historical and Institutional Shadows}

While the doctrinal implications of the Justice Department memo were intriguing, the President's more immediate concern was whether taking the Guarantee Clause route would serve his political interests. In April 1935, FDR dispatched the memo to congressional leaders and asked Felix Frankfurter to sound out their views. ${ }^{148}$ The initial reaction on Capitol Hill was negative, as Frankfurter told the President, "The wisdom of doing it is opposed to the unanimous judgment of the leaders of the party in both House and Senate whom I have consulted.... In light of this expert political advice, I assume the matter is to be dropped." resistance by Congress highlighted two problems with going after Huey Long by challenging his democratic credentials. ${ }^{150}$

First, using the Guarantee Clause was politically explosive in the South given the history of Reconstruction. To justify the military occupation following the Civil War, leading Republicans argued that the former Confederate states were in violation of this constitutional guarantee because of their denial of fundamental rights to AfricanAmericans. ${ }^{151}$ Thus, this textual provision evoked nightmares for the white establishment that supported Jim Crow. ${ }^{152}$ By brandishing such a controversial weapon against the Senator from Louisiana, FDR risked alienating a vital constituency and handing the South to Long in 1936. Furthermore, many Southern members of Congress feared that they would lose their seats to pro-Long candidates, which meant more to them than any dangers for the President. ${ }^{153}$

Second, the Guarantee Clause could not be activated without congressional consent, which meant that FDR would be ceding some control over the constitutional dimensions of the New Deal. Almost all

148. See supra text accompanying note 2. At this time, Frankfurter was on the Harvard Law faculty and acting as an informal advisor for the President.

149. SCHLESINGER, supra note 7, at 250-51.

150. The two problems that I am about to discuss were both spelled out in the letter to the President that was quoted earlier. See supra text accompanying notes 134-135.

151. See AKHIL ReEd Amar, AmericA's Constitution: A Biography 370-80 (2005) (offering a chronicle and a defense of the interpretation given to the Guarantee Clause by Reconstruction Republicans).

152. See HAIR, supra note 7, at 307 ("[FDR] shelved the idea because such action would surely have revived bitter memories of Reconstruction across the South.").

153. See KANE, supra note 4, at 126-27 ("By April the Democratic high command not only expected [Long] to defeat Senator Joseph T. Robinson of Arkansas and Senator Pat Harrison of Mississippi, two of the party's elder statesmen, in 1936, but was chewing its mustaches over statistics purporting to show that he could make himself political master of the whole, vast Lower Mississippi Valley ...." (quoting Raymond Moley)). 
presidents are loath to give Congress a greater role, and this White House was no exception. Indeed, when Congress attempted to write a constitutional amendment in 1937 as an alternative to FDR's Courtpacking plan, the President fought hard to block those efforts and ensure that he would retain command of the process by selecting new Justices who were sympathetic to his priorities. ${ }^{154}$ Of course, preserving executive prerogatives was of no value to FDR if the Kingfish drove him from office. The question was who posed the greater threat to the President's position: Huey Long or Congress?

\section{Constitutional Mobilization and a Hail of Bullets}

Ultimately, FDR and his congressional allies concluded that the danger from the Kingfish was too great to ignore. In a file on Long at Hyde Park, the President's home and official library, there is a draft resolution that to my knowledge has never been published until now. Here is the opening text of that resolution:

\section{A RESOLUTION}

Providing for the appointment of a special committee to investigate conditions in the State of Louisiana to determine if the State has a republican form of government.

WHEREAS, Section four of Article four of the Constitution provides that the United States shall guarantee to every State in this Union a republican form of government; and

WHEREAS, Responsible citizens charge that the State of Louisiana does not have a republican form of government and is operating under a dictatorship, and that corruption, intimidation and coercion of citizens exists in the State; therefore be it

RESOLVED by the House of Representatives:

1. That a special committee of five members of the House be appointed by the Speaker, with instructions to make a thorough and sweeping investigation of conditions in the State of Louisiana and submit its findings to the House from time to time as the inquiry proceeds .... ${ }^{155}$

This draft resolution is undated, and there is no other indication about what led to the decision to go ahead with the Guarantee Clause

154. See ACKERMAN, supra note 16, at 316-33 (providing a detailed narrative of the debate between the President and Congress over the appropriate response to the hostile decisions of the Supreme Court).

155. Draft Resolution, Official File 300, Box 19 (on file with the FDR Library). The rest of the draft resolution gave the committee broad authority to subpoena witnesses and documents related to its charge. See id. 
issue. Nevertheless, the presence of this document in the White House files suggests that FDR was involved in what was about to occur. ${ }^{156}$

When the House of Representatives finally took up the matter, the leadership used some trickery to get the ball rolling against Long. On August 27, 1935, a resolution was passed by the House, setting up a select committee "to investigate expenditures of candidates for the House of Representatives, and for other purposes." press discovered that "for other purposes" meant a Guarantee Clause inquiry into Louisiana. ${ }^{158}$ Anti-Long members of Congress said the committee would be "empowered ... to investigate Long's political organization, including his five-day State legislative sessions and their effect upon the republican form of government guaranteed by the Constitution." 159 Asked about the resolution, the Kingfish replied, "Let them come to Louisiana and investigate all they want .... They've already spent all the money appropriated for investigations in all the forty-eight States trying to get something on me and they haven't been able to do it yet." 160

Long moved swiftly to deal with the President's escalation of their feud. On September 7, 1935, he summoned the state legislature into special session and introduced a package of bills, including one

156. There is other circumstantial evidence that supports this view. FDR took a keen interest in the details of federal patronage in Louisiana. See WiLliams, supra note 5, at 795 ("Don't put anybody in and don't help anybody that is working for Huey Long or his crowd: that is a hundred per cent!" (quoting President Roosevelt)). He also took a personal interest in the FBI and IRS surveillance of Long, even selecting the head prosecutor. See supra text accompanying notes 119-121. It is therefore hard to believe that Congress would proceed with a Guarantee Clause investigation without the President's knowledge and approval.

157. White, supra note 6, at 249; see House To Inquire into Long Machine, Washington Hears, N.Y. TIMES, Aug. 28, 1935, at 1 ("The investigating resolution slipped through the House without one word of protest. Members considered it the routine resolution - adopted automatically every two years - setting up a committee of five to investigate and report on 1936 campaign expenses by candidates for the House.").

158. See HAIR, supra note 7, at 319 ("Not until the next day was it revealed that 'other purposes' meant a congressional probe of Huey Long's regime to determine whether Louisiana had a representative form of government as guaranteed by Article IV of the United States Constitution.”); House To Inquire into Long Machine, Washington Hears, supra note 157 , at 1 (" $[\mathrm{N}]$ ew language, reportedly inserted at the urging of anti-Long members, was disclosed today to have extended powers of the investigating committee far beyond customary limits.").

159. Louisianians Push an Inquiry of Long, N.Y. TIMES, Aug. 29, 1935, at 10; see id. (stating that "Speaker Grins over Issue"). According to the New York Times, "[a]nother objective of the investigation discussed at the Capitol would be an endeavor to prevent the Long organization from controlling the naming of delegates to the 1936 Democratic National Convention." House To Inquire into Long Machine, Washington Hears, supra note 157.

160. House To Inquire into Long Machine, Washington Hears, supra note 157; see WHITE, supra note 6, at 249 ("Huey knew, however, that if a House investigation requested intervention by the president, Roosevelt would gladly comply."). 
that made it a crime to violate the Tenth Amendment. ${ }^{161}$ An advisor told Long that the bill was unconstitutional (especially as applied to federal employees), but he replied that he did not care. ${ }^{162}$ While the Washington Post said this was "the broadest and boldest defiance of federal authority since the Civil War," the bill served Long's immediate political needs. ${ }^{163}$ For one thing, it would make it harder for the President to hamper his Senate reelection campaign. ${ }^{164}$ More important, the Kingfish's appeal to states' rights was designed to seize the South by drawing on its unhappy memories of the Guarantee Clause.

An epic political showdown was now on the horizon, but fate intervened the following day-September 8, 1935-when Long was assassinated. ${ }^{165}$ After his death, the repressive laws that the Kingfish supported were either repealed or left unenforced, and his Share Our Wealth movement vanished as a force in national politics. ${ }^{166}$ These stunning events raise an intriguing question: What impact did the assassination of Huey Long have on constitutional law?

\section{A COnStitutional Black Swan}

This Part explores how Long's unexpected death may have transformed the Constitution and the New Deal. ${ }^{167}$ First, the analysis

161. See WhITE, supra note 6, at 260; Long's Legislature Fights New Deal, N.Y. TIMES, Sept. 8, 1935, at 1 ("A challenge to Federal interference in the affairs of Louisiana, now under complete control of Senator Huey P. Long, whose domination is probably to be investigated by a Congressional committee, was offered at a special session of the Legislature convened tonight ....”).

162. See HAIR, supra note 7, at 317; see also WiLLIAMS, supra note 5, at 860 ("The bill did not spell out what constituted a violation, but it was obviously aimed at federal officials in the state and was designed to prevent them from performing their functions.").

163. WHITE, supra note 6, at 260-61.

164. See HAIR, supra note 7, at 317 ("He expected by litigation to tie up federal funds in Louisiana until after that election.”); Long's Legislature Fights New Deal, supra note 161 ("Senator Long proposes also at this session to provide for attacks in the name of the State in the Federal courts on any actions taken by the administration of President Roosevelt which may be obnoxious to the Senator or tend to injure the chances for the re-election of his State ticket in the January primaries.").

165. See SCHLESINGER, supra note 7, at 338-40 (describing the assassination).

166. See SINDLER, supra note 3, at 155; HUEY LONG, supra note 88.

167. Ever since Blaise Pascal speculated about the size of Cleopatra's nose, counterfactual history has been controversial. See Blaise PASCAL, PenseEs $\S$ II, at 59 annot. 162 (W.F. Trotter trans., Random House 1941) (1670) (asking how history would be different if Cleopatra had been ugly and did not seduce Mark Antony). Historians are usually skeptical about drawing causal conclusions because so many variables surround a given set of events. Lawyers, on the other hand, engage in counterfactual reasoning all of the time. See generally Robert N. Strassfeld, If . . . : Counterfactuals in the Law, 60 GEO. WASH. L. REV. 339 (1992) (giving a thorough, if somewhat abstract, analysis of the issue). When attorneys discuss "but 
assesses the doctrinal and institutional implications of the assassination assuming that Congress would have issued a report finding that Louisiana was violating the Guarantee Clause. ${ }^{168}$ In addition to making the phrase "republican form of government" a more important operational test for modern constitutional law, this congressional action could have outlined a new interpretive framework for the New Deal in a manner similar to what eventually occurred in landmark cases such as Palko v. Connecticut ${ }^{169}$ and United States v. Carolene Products Co. ${ }^{170}$ Second, the discussion probes the assassination's potential impact beyond the Guarantee Clause. With its gaze fixed on the abuses that Long was inflicting on Louisiana, either the Supreme Court or Congress might have crafted a significantly different body of law than what emerged in the Kingfish's absence on issues ranging from voting rights to the incorporation of the Bill of Rights. ${ }^{171}$ One larger lesson of this episode is that, while social movements are a powerful force shaping the law, more attention must be paid to the impact of highly improbable events that shock the constitutional system. ${ }^{172}$

for" cause or "harmless error," they are speculating on what would have occurred in the absence of some event.

This methodological distinction puts a legal historian in the sort of bind that other interdisciplinary scholars confront on a regular basis. In my view, a counterfactual analysis is appropriate and useful as long as it makes reasonable assumptions. See infra note 168 and accompanying text.

168. In other words, I make no assumption about the remedy that might have been used against Louisiana, the implications for the 1936 national elections, or the possibility of a future Long presidency. Certainly someone could spin out an interesting tale about all of these scenarios, but the causal problems multiply the further one ventures from the assassination itself.

With respect to the assumption of congressional action, the likelihood that the House Committee would have issued a report without the assassination was high, given the events leading up to its formation and Long's decision to escalate the crisis shortly before his death. Moreover, it is reasonable to conclude that this report would have found at least some aspects of the state government so obnoxious that the Guarantee Clause would have been invoked, largely due to the public outcry and the President's desire to undermine Long's credibility.

169. 302 U.S. 319 (1937).

170. 304 U.S. 144 (1938).

171. In other words, the substance of the law coming out of the New Deal would have changed whether Congress used the Guarantee Clause (and thereby exerted a strong influence on the Court) or whether that challenge to Long came solely from litigation initiated in Louisiana.

172. See Magliocca, supra note 62, at 74-86 (explaining how the unexpected death of President William Henry Harrison saved McCulloch v. Maryland from being overruled). For a provocative meditation on the disproportionate role that these rare "black swans" play in our lives, see Nassim Nicholas Taleb, The Black Swan: The Impact of the Highly IMPROBABLE (2007). 


\section{A. The Guarantee Clause and Judicial Supremacy}

Perhaps the most obvious legal consequence of Long's death was that it marked the end of the Guarantee Clause as a vital force in constitutional discourse. Although nothing prevents Congress from invoking this textual provision today, since 1935 there has been no serious discussion of doing so. One could say that this is so because no threat on the scale of what Long represented has appeared since then, but that conclusion is a little too convenient. An equally, if not more persuasive argument can be made that Congress would be more inclined to rely upon the Guarantee Clause today if a precedent for such action had been created during the 1930s. In other words, the Guarantee Clause would have taken its place, with the Commerce Clause and Section 5 of the Fourteenth Amendment, as a powerful weapon in the congressional arsenal to address inequities in the states. ${ }^{173}$ Unlike Section 5 of the Fourteenth Amendment, though, the Guarantee Clause contains no state action requirement, and, unlike the Commerce Clause, the Guarantee Clause is not subject to judicial review. ${ }^{174}$ Thus, the dormancy of the "republican form of government" test since the 1930s is significant.

Furthermore, Long's assassin deprived Congress of a golden opportunity to establish the constitutional baseline for the New Deal. While Congress's conclusion that a state is violating the Guarantee Clause is nonjusticiable, that finding is quite significant for the interpretation of other constitutional provisions. To understand how Congress could have influenced the tenor of New Deal jurisprudence, consider what its report on the Guarantee Clause would have looked like. ${ }^{175}$ The State of Louisiana could not be branded as a dictatorship

173. Risa L. Goluboff puts forward a related counterfactual thesis about Section 2 of the Thirteenth Amendment, which was seen by New Deal-era civil rights lawyers as the tool of choice to attack discrimination before the Equal Protection Clause took on that role. See generally RisA L. Goluboff, The Lost Promise OF Civil Rights (2007) (making this argument). Whereas the fall of the Guarantee Clause alternative was sudden and can be traced to one unlikely moment, the shift from a focus on the Thirteenth Amendment to the Fourteenth was much more subtle and complex.

174. See United States v. Morrison, 529 U.S. 598, 621-27 (2000) (reaffirming that the Fourteenth Amendment contains a state action requirement). While the state action point is not obvious from the words "republican form of government," if Don Corleone were left untouched by a state and gained power over its citizens, the argument that Congress could not act because this was a problem created by state inaction would be unconvincing. That interpretation is reinforced by the Guarantee Clause's statement that "domestic violence" or anarchy, which is the essence of state inaction, is a sufficient basis for congressional action. See U.S. CONST. art. IV, $\S 4$.

175. There is an analogy here to the Report of the Joint Committee on Reconstruction, which documented abuses in the South following the Civil War and served as a blueprint for 
unless specific practices in the state had been identified as defective, and there are at least two areas that could have met this standard. First, Congress could have pointed to violations of individual rights so fundamental that free government could not exist without them. Second, the inquiry could have held that the structure of government (for example, the procedures of the legislature or the restriction of judicial review) was so flawed that the state could not be described as republican in form.

No matter which of these paths Congress had chosen, its reading of the Constitution would have exerted a pull on the Supreme Court. ${ }^{176}$ For instance, suppose that Congress had determined that the failure of Louisiana to protect citizens from warrantless searches was a Guarantee Clause problem. When the Justices took up the issue of whether the warrant requirement should be applied to the states, they could hardly have ignored this conclusion. In the hypothetical, Congress would be saying that a warrant for searches was "implicit in the concept of ordered liberty" such that the failure to guarantee this right would put a state beyond the constitutional pale. ${ }^{177}$ The Supreme Court would have been hard pressed under these circumstances to say that the same requirement did not apply to all of the other states. ${ }^{178} \mathrm{~A}$ similar logic would apply to any finding by Congress about the Long organization that supported its Guarantee Clause reasoning. This suggests that any report by Congress addressing Louisiana could have become a major source of guidance on how constitutional law would be read and synthesized with prior authority in the wake of the New Deal. ${ }^{179}$

the Fourteenth Amendment. See H.R. REP. No. 39-30 (1866). One difference between that text and the missing report on Long is that it is very doubtful that Congress would have followed up the latter with a constitutional amendment.

176. One issue that needs clarification is what I mean by "Congress" in this context. A report issued by the Select House Committee is not the same thing as a report by Congress as a whole. While it was almost certain that the Committee would have issued a Guarantee Clause report about a live Huey Long, it is not as clear whether the entire Congress would have endorsed this report. To a certain extent, this only goes to the amount of persuasive authority of such a statement, but in any case the congressional leadership's decision to proceed after having been opposed to an inquiry suggests that they felt confident about the passage of such a resolution through both chambers.

177. Palko v. Connecticut, 302 U.S. 319, 325 (1937). I use the language from Palko deliberately to underscore the interchangeability between the Guarantee Clause and the case law on incorporation.

178. The opposite would also be true, though perhaps not to the same degree. If Congress expressly stated that the denial of a right was not inconsistent with the Guarantee Clause, the Court might well be persuaded to say that the right was not fundamental.

179. Of course, none of this happened, and the Court seized control of the constitutional agenda. Indeed, one striking fact about Footnote Four of Carolene Products, 
Finally, congressional action would have set a precedent for a model of coordinate constitutional interpretation and undermined the more robust claims of judicial supremacy. ${ }^{180}$ Such a precedent would have been especially powerful in the midst of the New Deal when constitutional law was passing through a crisis of legitimacy. Though the Supreme Court would have retained the final word in almost all areas of doctrine, Congress would have been emboldened to shape constitutional norms, and, in many cases, the Justices would have been obliged to follow, either as a matter of comity or custom. Going beyond this institutional observation would probably be too speculative, but one point is clear: the standard narrative of the New Deal needs some revision. Instead of describing 1937 as the annus mirabilis in which the Justices lost power to Congress and the President, scholars must also look to September 1935 as the moment when the Court won a decisive victory over Congress through pure luck and judicial supremacy escaped to fight another day.

\section{B. New Substantive Priorities}

After Long was killed, Hodding Carter wrote, "Had all Americans lived some of those years under him, democracy would be more secure today, because democracy would have come to have a more precious meaning., ${ }^{181}$ In other words, constitutional doctrine

which was an important opening step in defining the new legal order, is that its nominees for heightened judicial scrutiny focused on many of the same concerns that were expressed about Long's Louisiana. In particular, Footnote Four explained that a statute "which restricts those political processes which can ordinarily be expected to bring about repeal of undesirable legislation" was presumptively invalid. United States v. Carolene Prods. Co., 304 U.S. 144, 152 n.4 (1938). To reinforce this point, the Court gave four examples that could have come right out of the Long playbook: (1) "restrictions upon the right to vote," (2) "interferences with political organizations," (3) the "prohibition of peaceable assembly," and (4) "restraints upon the dissemination of information." Id. at 152-53 n.4. On the last of these issues, Footnote Four even cited a case invalidating Long's advertising tax imposed against hostile state newspapers. Id. at 153 n.4 (citing Grosjean v. Am. Press Co., 297 U.S. 233 (1936)). Thus, Footnote Four can be seen as a functional equivalent of the aborted congressional inquiry into Senator Long.

180. Oddly enough, the aborted congressional action with respect to Louisiana may have led the Court to adopt a more restrained posture in situations where a congressional remedy was possible. As my colleague Michael Pitts pointed out to me, one cannot help but notice that Justice Frankfurter was the liaison between FDR and Congress on the Guarantee Clause issue. A decade later, he wrote in Colegrove v. Green that the courts should avoid the "political thicket" and refrain from acting on claims of state malapportionment. 328 U.S. 549, 556 (1946) (plurality opinion). While to modern eyes this sort of judicial deference seems unrealistic, Frankfurter's experience with Long might have led him to think that seeking a remedy in Congress was a bona fide alternative when the citizens of a state were deprived of their voting rights.

181. Carter, supra note 51, at 363. 
might have taken on a different meaning in the shadow of the Kingfish. While in some cases his tyranny could have expedited developments that did not come to fruition until the 1960s, in a few areas Long's assassination may have altered the landscape more permanently.

Whether Congress or the Court took the lead, the impact of using the abuses in Louisiana as a starting point for reconstructing the definition of individual liberty and federal/state relations could have been substantial. In our common law system, the facts that are presented alongside the initial interpretation of a constitutional text or principle matter a great deal. ${ }^{182}$ From a jurisprudential standpoint, such a connection memorializes certain wrongs and turns them into a common reference for legal reasoning. ${ }^{183}$ Using Long's dictatorship as a wellspring for reading the Guarantee Clause or the Bill of Rights would have put his acts on par with the cruelty of segregation or the policies of George III as an example of what not to do in constitutional law. ${ }^{184}$ Although this "anti-canonical" form of reasoning can be dismissed as nothing more than rhetoric, history shows that these counterexamples are very persuasive. ${ }^{185}$

182. Perhaps the best example is the Slaughter-House Cases, which construed the Fourteenth Amendment for the first time in litigation brought by whites seeking to vindicate economic rights rather than by African-Americans concerned about political or civil rights. See 83 U.S. (16 Wall.) 36 (1873); 1 Bruce Ackerman, We the People: Foundations 95 (1991) (describing the litigation).

183. Instead, there is only one Supreme Court case that addresses what Long did to his state. In Grosjean v. American Press Co., the Justices struck down the Senator's advertising tax on newspapers. See 297 U.S. at 250-51 ("[N] o state during the one hundred fifty years of our national existence has undertaken to impose a tax like that now in question."); see also supra text accompanying notes 82-84 (describing Long's attempt to control opposing press by levying a two percent tax on papers with large circulations). Yet the Court never mentioned Long by name (now that he was dead) and spent most of its time discussing English and colonial precedents. See Grosjean, 297 U.S. at 245-48. Thus, there is nothing significant in the Congressional Record or the United States Reports that describes what happened in Louisiana during the 1930s.

184. The only evidence that this occurred with respect to Long came during the debate over FDR's Court-packing plan, when a witness compared the President's proposal to the tactics of the Kingfish. Reorganization of the Federal Judiciary: Hearings on S. 1392 Before the S. Comm. on the Judiciary, 75th Cong. 868 (1937) (statement of Dorothy Thompson) ("That was a common condition in the State of Louisiana during Huey Long's regime. When the supreme court invalidated some of his laws, he put in men who would support them. We were all very much outraged by that at the time. I want to ask whether there is any difference essentially from what is proposed here?").

185. See, e.g., J.M. Balkin \& Sanford Levinson, The Canons of Constitutional Law, 111 HARV. L. REV. 963, 1018-19 (1998) (explaining the concept of an "anti-canon"); PRIMUS, supra note 20, at 207-20 (explaining how the theme of "anti-totalitarianism" shaped the case law during the Cold War). 
On a more practical note, the most significant change that probably did not happen for a long time because of the assassination was federal enforcement of voting rights. The corruption of the election system in Louisiana was the chief flaw cited by Long's opponents. ${ }^{186}$ At that time, however, there was not much that federal authorities could do about this, as FDR indicated in another press conference after he was asked about Long's declaration of martial law in New Orleans:

Q: Do you think the Constitution has been violated there?

THE PRESIDENT: We had a very funny thing. Some of those people - this is off the record entirely-asked an opinion as to when the Constitution was violated. I got the Attorney General's office to write an opinion, and, of course, there isn't anything to be done on the situation as it exists today, not a thing. There isn't a precedent in history for it.

Q: There probably wouldn't be a precedent before Election Day- I mean if they were to have any interference with the balloting.

THE PRESIDENT: Again, it is a primary election.

Q: The Federal laws do not cover a primary?

THE PRESIDENT: No, in no shape, manner or form. We are all sorts of tied up and, of course, Huey Long knows it. ${ }^{187}$

With the Senator making a mockery of a free and fair count, pressure would have mounted for Congress to act and enlarge the federal role in supervising voting. ${ }^{188}$ An early version of the Voting Rights Act would have made it that much easier for future reformers to extend suffrage rights to African-Americans in the South over objections grounded in federalism.

Another critical development that may have been delayed by Long's death was the incorporation of the Bill of Rights. ${ }^{189}$ To state the

186. See supra text accompanying notes 76-79, 124-126, 128.

187. Press Conference No. 142, in 4 PRESS CONFERENCES, supra note 128, at 57-58.

188. Without congressional action, the Court could have used the reasoning that first appeared during the 1960s in cases relying on equal protection. See, e.g., Reynolds v. Sims, 377 U.S. 533, 555 (1964) ("'[T] he right of suffrage can be denied by a debasement or dilution of the weight of a citizen's vote just as effectively as by wholly prohibiting the free exercise of the franchise.").

189. The strongest candidate for immediate incorporation was the warrant requirement of the Fourth Amendment, which was not applied to the states through the exclusionary rule until the 1960s. See Mapp v. Ohio, 367 U.S. 643, 660 (1961); supra text accompanying note 34 (pointing out that the Louisiana BCI could make arrests without warrants). Another area of interest was the Second Amendment, which is not incorporated even today. See Presser v. Illinois, 116 U.S. 252, 265 (1886) (stating that the "amendment is a limitation only upon the power of Congress and the National government, and not upon that of the States"); see also discussion supra note 101. The trial procedures set forth in the Fifth and Sixth Amendments 
obvious, Louisiana was full of plaintiffs who could claim that their individual rights were being violated by the state. The critical point, though, was that the context surrounding these cases made it more likely that the Supreme Court would have held that these liberties were fundamental and therefore binding upon the states. Rather than seeing each claim in isolation, which would tend to diminish its significance, the Justices would learn (either from litigants or from Congress using the Guarantee Clause) that these cases were the result of a system designed to concentrate political power in an unprecedented manner. Under these conditions, the rejection of any incorporation claim would look like an endorsement of Long's overall behavior, which might have been a bitter pill for the Court to swallow.

Finally, the assassination struck a blow for federalism by discouraging more exacting federal scrutiny of the structure of state government. In large part, what made Louisiana an authoritarian regime was the way in which the Kingfish eliminated the ability of dissenters to challenge the machine in the legislature, the courts, or local government. Unlike voting rights and incorporation, though, neither Congress nor the courts impose significant limits on how a state may organize itself. States can choose to have elected or appointed judges, a bicameral or unicameral legislature, and robust or nonexistent local government. Surprising as it might sound, most of the procedural innovations that Huey Long introduced are still not barred by federal law. ${ }^{190}$ But action under the Guarantee Clause or a searching judicial inquiry into the administration of Louisiana could have put a leash on state government operations and created a new body of doctrine for constitutional attorneys to master.

In sum, the Kingfish's death neutered the Guarantee Clause, prevented Congress from taking on a more muscular role in defining constitutional norms, and probably delayed federal protection of many basic rights for a generation. Thus, it is hard to avoid the conclusion that the most powerful legal reformer during the New Deal was a doctor-Carl Austin Weiss, the assassin of Huey Long. ${ }^{191}$

might also fit within this analysis, though I have not undertaken the survey of past criminal justice in Louisiana necessary to reach a conclusion.

190. For instance, there is no federal constitutional doctrine holding that state legislatures must have committees or permit minority rights on the floor. Nor is there any requirement that a state must adhere to separation of powers or allow anything more than minimal judicial review in its courts.

191. See SCHLESINGER, supra note 7, at 339 . 


\section{CONCLUSION}

A tombstone in front of the capitol in Baton Rouge reads, "Here lies Louisiana's great son Huey Pierce Long[,] an unconquered friend of the poor who dreamed of the day when the wealth of the land would be spread among all the people." ${ }^{192}$ Though dimmed by the passage of time and the glow that now surrounds the presidency of FDR, it is easy to forget that millions of citizens saw the Senator as their best hope for a brighter future. Much like the death of Robert F. Kennedy a generation later, Huey Long's murder shattered these hopes and left many to wonder whether America would have been a more just country had he lived.

Nevertheless, the most important lesson of this period comes not from what might have happened, but from what did happen. A single charismatic leader operating in a time of political turmoil came within a whisker of destroying democracy in Louisiana and staking his claim to the White House. Only violence, not reason, removed this threat. Whether out of a sense of shame or neglect, legal scholars have never reckoned with these facts. Thus, one goal of this project is to spur interest in the Kingfish and open up new paths for research on the Guarantee Clause and on the rule of law.

The other powerful theme that emerges from Huey Long's career is the fragility of constitutional law. Even in the United States, a single charismatic leader can, under the right circumstances, demolish deeply entrenched institutions and practices. Likewise, a single assassin can turn aside the march of millions and transform the work of the courts. We cannot be blasé about ideas that threaten the values we hold dear in the belief that the sheer weight of numbers will save the day. Whether the danger comes from tyrants or from random acts of violence, freedom requires all of us to stand and be counted when liberty is in peril.

192. The source of the quote comes from the author's visit to Long's gravesite on April 26, 2007. 